\title{
A techno-typological analysis of fan (tabular) scrapers from Ein Zippori, Israel
}

\author{
Katia Zutovski ${ }^{1}$, Richard W. Yerkes ${ }^{2}$, Aviad Agam ${ }^{1}$, Lucy Wilson ${ }^{3}$, \\ Nimrod Getzov ${ }^{4}$, Ianir Milevski ${ }^{4}$, Avi Gopher ${ }^{1}$ \\ 1. Department of Archaeology and Near Eastern Cultures, Tel Aviv University, Israel. \\ Email: Zutovski: katiaz@mail.tau.ac.il; Gopher: agopher@post.tau.ac.il; Agam: aviadkra@post.tau.ac.il \\ 2. Department of Anthropology, The Ohio State University, U.S.A. Email: Yerkes: yerkes.1@osu.edu \\ 3. Department of Science, Applied Science and Engineering, University of New Brunswick, Canada. \\ Email: 1wilson@unb.ca \\ 4. Israel Antiquities Authority, Israel. Email: Getzov: getzov@israntique.org.il; \\ Milevski: ianir@israntique.org.il
}

\begin{abstract}
:
Fan (or tabular) scrapers are a diagnostic tool type in Chalcolithic Ghassulian and Early Bronze Age lithic assemblages from the southern Levant. To date, only small numbers of fan scrapers have been reported from the Late Pottery Neolithic Wadi Rabah culture. In this paper we present a technotypological analysis of a fair sample of fan scrapers and fan scrapers spalls from Wadi Rabah and Early Bronze Age layers at Ein Zippori, Lower Galilee, Israel. Techno-typological similarities and differences of Wadi Rabah, Chalcolithic Ghassulian and Early Bronze Age fan scrapers from Ein Zippori and other sites in the region are presented, trends of change along time are noted, and an updated definition is proposed. Our results indicate that fan scrapers are highly efficient tools for accurate and prolonged animal butchering and hide working. The main advantage of fan scrapers is their mostly flat, thin morphology and large size that permits the creation of several relatively long working edges, various retouched angles (from sharp to abrupt), extensive resharpening, and a comfortable grasp. While fan scrapers were products of a local trajectory in Late Pottery Neolithic Wadi Rabah lithic industries at Ein Zippori, a standardized, off-site manufacturing of fan scrapers is evident during the Early Bronze Age.
\end{abstract}

Keywords: fan scrapers; tabular scrapers; Wadi Rabah culture; Early Bronze Age; Southern Levant

\section{Introduction}

Fan (or tabular) scrapers are a diagnostic tool type in Chalcolithic Ghassulian (CHG) and Early Bronze Age (EBA) lithic assemblages from the southern Levant (e.g., Bar-Yosef et al. 1977; Crowfoot-Payne 1983: 720-721; Rosen 1983; 1997: 78-79; 2013: 402; Levy \& Alon 1985; Greenhut 1989; Marder et al. 1995; Noy 1998; Fujii 1999; Bankirer \& Marder 2003; Beit-Arieh et al. 2003; van den Brink et al. 2004; Blockman \& Groman-Yeroslavski 2006; Rowan 2006; Milevski 2013). Typological differentiation in fan scrapers between these two periods was noted by Abe (2008) and will be discussed below. To date, only small numbers of

Published by the School of History, Classics and Archaeology, University of Edinburgh ISSN: 2055-0472. URL: http://journals.ed.ac.uk/lithicstudies/

This work is licensed under a Creative Commons Attribution 2.5 UK: Scotland License. 
fan scrapers have been reported from lithic assemblages of the Late Pottery Neolithic Wadi Rabah (WR) culture (Kaplan 1969; Gopher 1989: 119; Barkai \& Gopher 2012: 837; Khalaily 2011; Khalaily \& Nagorsky 2013). In this paper we present a techno-typological analysis of fan scrapers from WR and EBA layers of Ein Zippori, Lower Galilee, Israel (Milevski \& Getzov 2014; Milevski et al. 2014). Functional analysis of Ein Zippori fan scrapers is presented elsewhere (Yerkes et al. 2016). Contextual, spatial, and symbolic aspects of Ein Zippori fan scrapers are beyond the scope of this paper, and will be dealt with separately.

Excavations at Ein Zippori were conducted by the Israel Antiquities Authority between the years 2011 and 2013. Excavation areas A to $\mathrm{N}$ contained layers assigned to the WR culture, here ascribed to the late Pottery Neolithic (PN) (the excavators labelled these layers as Early Chalcolithic) and to the EBA. Altogether, a total of ca. 5000 sq. $\mathrm{m}$ has been excavated (Milevski \& Getzov 2014; Milevski et al. 2014). The site is located in the lower Galilee, $2 \mathrm{~km}$ near Nazareth in the basin of Nahal Zippori, a region with quite many late prehistoric sites (see Figure 1) (Barzilai et al. 2013: 22-23). Several researchers studied multiple aspects of the site of Ein Zippori (Barzilai et al. 2013; Milevski et al. 2014; 2015a; 2015b; in press.; Namdar et al. 2015; Schechter et al. 2016a; 2016b; Yerkes et al. 2016; Agam et al. in press; Parush et al. 2016; Wilson \& Agam 2016) The present study is part of the Ein Zippori lithic project carried out at the Institute of Archaeology, Tel Aviv University.

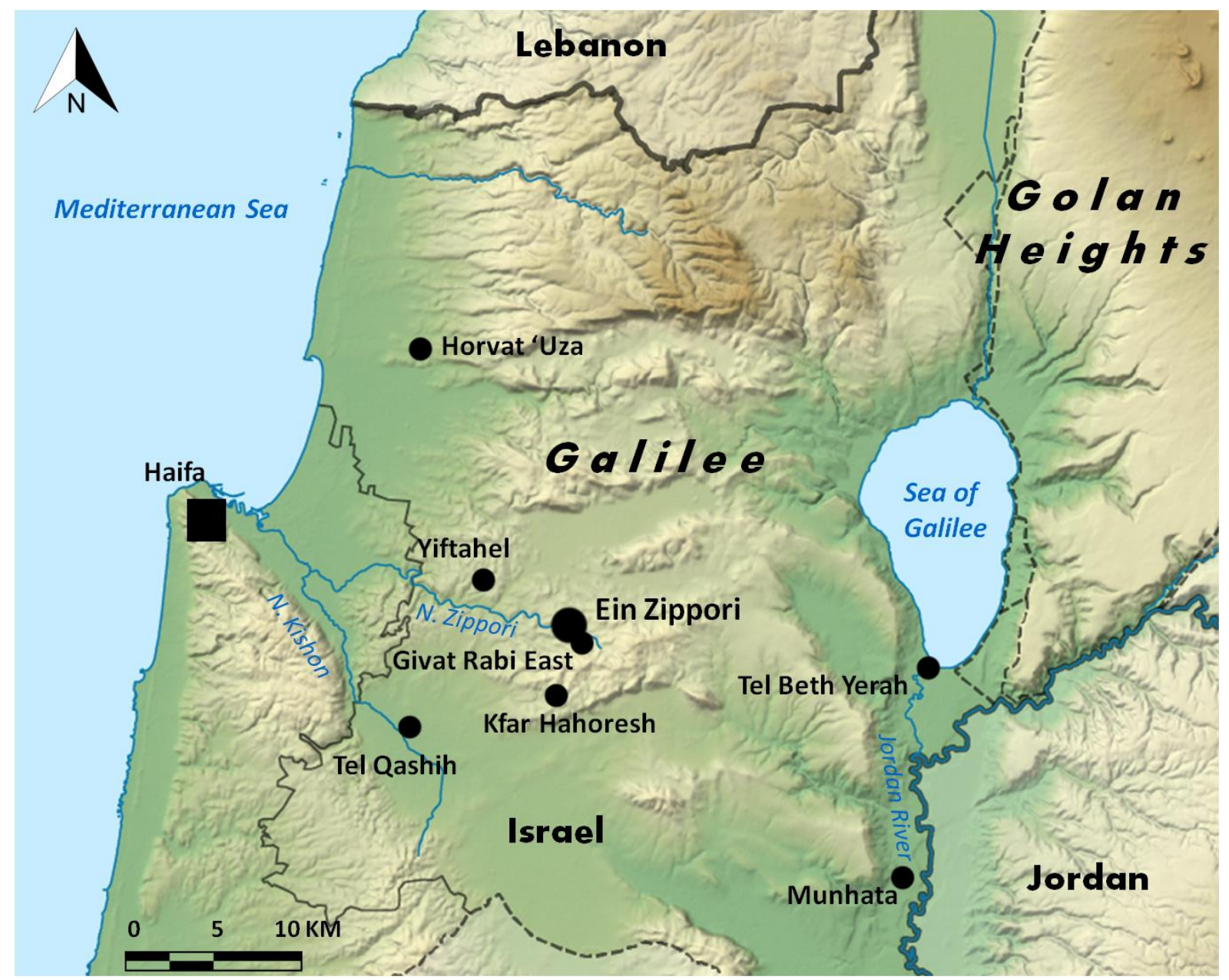

Figure 1. Ein Zippori location map. 
The aims of this paper are:

- To present a detailed techno-typological analysis of WR and EBA fan scrapers as well as fan scraper spalls from Ein Zippori.

- To summarize the available evidence on techno-typological differences and similarities of WR, CHG and EBA fan scrapers from other sites in the region.

- To propose a detailed definition of fan scrapers.

- To briefly discuss the results of the techno-typological analysis in relation to the functional study of fan scrapers from Ein Zippori, and to the socio-economic changes between the WR and EBA.

\section{Fan scrapers: A history of research}

\subsection{Definition}

Rosen (1983) defined these tools as follows, "Tabular scrapers, often referred to in the literature as fan-scrapers, are large scrapers or knives, manufactured on flat cortical flakes that vary considerably in size and shape". A somewhat open definition for fan scrapers was made by Quintero et al. (2002: 17) "The fan scraper "type" has been shown to be one expression of a broad and continuous array of sizes and morphological configurations now all subsumed under the "tabular scraper" rubric...In the context of the Chalcolithic and Early Bronze ages, tabular scrapers are frequently recognized typologically as originating from very large, flat flakes (often with distinctive, multifaceted platforms) of characteristic Eocene flint". Recent definitions of scrapers and blanks include that of Abe (2008: 115, 423, 429) "Tabular scrapers are scrapers or knives made on thin, flat and large cortical flakes. They are also referred to as fan scrapers"; Fujii (2011: 1) "Tabular scrapers are palm-size retouched flake tools used for a range of purposes"; and Müller-Neuhof (2013: 221) "Cortical scraper blanks are thin, flat flakes and are often palm-sized".

Most agree that fan scrapers are made on 'flat cortical flakes'. However, it is not clear whether the flatness refers to the dorsal face or the ventral face, or both. Abe (2008) and Müller-Neuhof (2013) include the term 'thin' without any further details. Moreover, while there are thin fan scrapers, similar tools made on flakes that are 'not thin' (from 1.5 to $2 \mathrm{~cm}$ thick) have been found in PN, CHG, and EBA lithic assemblages (Crowfoot-Payne 1983: 720-721; Greenhut 1989; Rosen 1993; Marder et al. 1995; McCartney \& Betts 1998; Bankirer \& Marder 2003; Yannai \& Ariel 2006; Barkai \& Gopher 2012: 838, 839; Akkermans et al. 2014). This was the case at Ein Zippori. In defining 'size', the citations from Rosen (1983) and Quintero et al. (2002) contain an internal contradiction, deriving probably from the intensively resharpened and broken state of some fan scrapers. Others (Fujii 2011; MüllerNeuhof 2013) use the term 'palm-sized'. In our view, however, size cannot be used to define fan scrapers since there is evident variation in size that probably resulted from repetitive resharpening. Apparently, no consensus is evident in the retouch of fan scrapers. 'Retouch' is part of all of the above definitions of these 'scrapers', but it is not defined (see the section regarding technology and typology below). We believe that the issue of retouch is not dealt with for a good reason: e.g., fan scrapers from Ein Zippori vary in angles of retouched edges from sharp to abrupt. In our view, the inconsistency in definitions of fan scrapers derives from the fact that this tool type varies considerably, typologically and technologically, from the WR to the EBA periods.

\subsection{Chronology and geographical distribution}

Fan scrapers are a hallmark of the CHG and EBA. They are present at least until the end of the EBAIII period, when they seem to disappear (Rosen 1983; 1997: 75; Quintero et al. 
2002; Fujii 2011). Yet, fan scrapers appear already in the late PN (Kaplan 1969; Gopher 1989: 119; Barkai \& Gopher 2012: 837; Khalaily 2011; Khalaily \& Nagorsky 2013). Comments on the presence of fan scrapers in early PN Yarmukian assemblages such as Shaar Hagolan and Jabel Abu Thawwab (Stekelis 1972; Wada 2001; Abe 2008: 411-412) are dubious and should be considered with caution. However, rounded and elongated, relatively flat and thin scrapers on flakes, with or without cortex, appear in small numbers in early PN sites (Yeivin \& Olami 1979; Khalaily et al. 2015: 30, figs. 18.4-6). Earlier appearances of fan scrapers, in Pre-Pottery Neolithic C (PPNC) Yiftahel for example, are most likely intrusive (Khalaily 2006: 82, 85).

Fan scrapers are known throughout the southern Levant (Israel and Jordan) with more frequent occurrences in southern regions such as the Negev and Sinai, and reduced numbers as one goes northwards (Rosen 1983; Beit-Arieh et al. 2003; Milevski 2013). However, according to Abe (2008: 420-424), the number of fan scrapers in lithic assemblages increased drastically in central Israel during the EBA. There are claims that fan scrapers also occur in assemblages from Syria, Egypt (Rosen 1983; Rizkana \& Seeher 1988: 29-31; Stępień 2012) and in southeastern Anatolia, the middle Euphrates area in northern Syria and perhaps in southern Mesopotamia in the Uruk culture (Müller-Neuhof 2006).

\subsection{Raw material and procurement patterns}

Large scale quarry and workshop sites (some over 12 ha in area) with many fan scraper blanks have been discovered in southern and north eastern Jordan (Fujii 1998-2002; 2006; Quintero et al. 2002; Müller-Neuhof 2006; 2013). Smaller workshops have been found in southern Israel (Rosen 1983; 1997: 71, 75). The abundance of large blocks of flint with one or more sizable cortical flake removals, platform-preparation flakes, discarded cortical flakes, and hammerstones on the surface of these sites indicates that they were loci for fan scraper production (Rosen 1983; Fujii 1998-2001; Quintero et al. 2002; Müller-Neuhof 2006; 2013). Flake scars on el-Jafr Eocene flint cores are often $20 \mathrm{~cm}$ across with an average between 10 and $15 \mathrm{~cm}$. The current hypothesis is that fan scraper blanks and shaped scrapers were transported into settled Mediterranean zone from these regions through an organized network of exchange or trade (Rosen 1983; 1997: 75; Milevski 2013). It is suggested that pastoral nomad populations were involved in quarrying flint at el-Jafr basin and Wadi ar-Ruwayshid on a seasonal basis, producing cortical flake blanks, shaping them (or part of them), and transporting the finished tools or the blanks directly to consumers (Rosen 1983; Quintero et al. 2002; Abe 2008; Müller-Neuhof 2006; 2013; Fujii 2011).

\subsection{Typology and technology}

Rosen (1997: 74) presented a general typology based on shape (length:width ratio). He described fan scrapers as oval, round, elongated and fan shaped. Abe (2008: 415-424) analyzed Chalcolithic (mostly CHG but also some WR) and EBA fan scrapers and claimed that most CHG fan scrapers were made on large, side-struck, thin cortical blanks. Most of them are fan shaped, with bulbs of percussion commonly removed with ventral flat and invasive retouch. EBA fan scrapers were made on large and thin end struck blanks, and are mostly oval and elongated, while bulb thinning with ventral invasive retouch is rarely observed, and dorsal retouch prevails (Marder et al. 1995; Abe 2008: 415-424).

Published accounts of technological features of fan scrapers propose that most cores used to produce fan scrapers were "...large flint nodules with flat cortical surfaces..." (Rosen 1983). Fan scraper blanks "... vary from 5 to $15 \mathrm{~cm}$. in length and width" (Rosen 1983). Rosen et al. (2006) made a differentiation between cortical scrapers and tabular scrapers. They claim that cortical scrapers "... are smaller, derive from smaller cobbles, do not show 
especially flat dorsal surfaces and were produced on site". On the contrary, tabular scrapers "...show flat cortical surfaces and in fact derive from large nodules of fine-grained Eocene flint, and seem to be manufactured elsewhere and brought in to the site". Abe (2008: 412) refined this observation by adding a chronological distinction. He claimed that blanks for PN fan scrapers "... may be on normal thick cortical flakes...usually small, less than $9 \mathrm{~cm}$ in length", while EBA fan scrapers were mostly "... over $12 \mathrm{~cm}$ in length" (Abe 2008: 422).

Thus, Abe's (2008) detailed technological analysis managed to distinguish fan scrapers dating to the PN from the later CHG and EBA fan scrapers. At the end of the PN a scraper type (referred to as a 'cortical scraper' by Rosen et al. (2006)) made on regular cortical flakes from smaller cores of local raw material appears (Quintero et al. 2002; Rosen et al. 2006; Abe 2008). Typologically, these are round and oval tabular scrapers (Abe 2008: 415-424) without especially flat dorsal surfaces (Rosen et al. 2006). Rosen et al. (2006) consider a flat dorsal face as a distinguishing trait between 'cortical scrapers' and fan scrapers. We accept this distinction because blanks with a flat dorsal face must have been detached from flat nodules with cortex. It is notable that quarry sites with these flat cores retaining cortex that have negatives of fan scrapers have not been found in the Mediterranean zone of southern Levant (Rosen 1983; 1997). Moreover, the CHG and the EBA fan scrapers are claimed to be made on blanks struck from cores of imported raw material from specific sources (Rosen 1983; 1993; Fujii 1998-2002; 2006; Quintero et al. 2002; van den Brink et al. 2004; Milevski 2013). Technologically, flat blanks with abundant cortex are the result of a distinct production trajectory.

Incisions on the cortex were reported from EBA sites solely (Greenhut 1989; Marder et al. 1995; Beit-Arie et al. 2003: 190; Abe 2008: 423; Milevski 2013 and references therein). Recently, Rosen (2013) proposed that incisions on the cortex are more common in the Mediterranean zone and almost absent from desert sites.

\subsection{Other aspects}

The function of fan scrapers is under debate. It has been suggested in the past that fan scrapers could have been used for wood-working, plant processing, sheep shearing, butchering activities, and for ritual practices (McConaughy 1979; 1980; Rowan \& Levy 1991; Unger-Hamilton 1991: 152; Henry 1995: 372-373; Barket \& Bell 2011). However, recently Yerkes et al. (2016) examined microwear traces on a large sample of fan scrapers and their spalls from Ein Zippori and concluded that those fan scrapers were used for skinning and butchering animals, as well as for working hide and bone.

Apart from their everyday functions, fan scrapers are sometimes described as ceremonial or symbolic artifacts because of their common occurrence in what have been interpreted as ritual contexts (McConaughy 1980: 53). For example, more than 400 fan scrapers were found at Mitzpe Shalem, clustered together in close relation to a burnt built platform (bama), a hall or foundation of a hall, and a stone-built installation interpreted as a silo (Greenhut 1989). Fan scrapers spalls were retrieved from the open court and the adjacent corridors of the Megiddo EBAIb temple (Shimelmitz \& Adams 2014); fan scrapers were the predominant flint tool associated with the Masseboth in Negev and Sinai (Avner 2002: 76 and see references and details therein). The evidence for deliberate breakage of fan scrapers (Rosen 2013), and the incisions that sometimes appear on their cortex (Kochavi 1969; Greenhut 1989; Marder et al. 1995; Rosen 1997: 75; Milevski 2013 and references therein) were used to support this view. Fan scrapers were also retrieved from burial contexts e.g., ossuaries, cist graves, burial caves, nawamis and tumuli, predominantly of the CHG and EBA (Bar-Yosef et al. 1977; Levy \& Alon 1985; Rosen 1997: 74; Beit-Arieh et al. 2003; van den Brink et al. 2004; Fujii 2006; Bron 2010; Avrutis et al. 2012: 214; Getzov 2013). The symbolic aspect of fan scrapers is 
only briefly mentioned here, and will be dealt with in the future in relation to the excavated contexts at Ein Zippori.

\section{Material and analysis}

We have analyzed fan scrapers from Late Pottery Neolithic WR (early and late) and EBA (mostly EBAIb but also some EBAII) layers of Ein Zippori using the fan scraper definitions of both Rosen $(1983 ; 1997)$ and Abe (2008). Most fan scrapers were retrieved from secure stratigraphic contexts $(\mathrm{N}=118)$ following pottery analysis $(\mathrm{N}$. Getzov), yet a significant number of fan scrapers $(\mathrm{N}=73)$ were retrieved from top soil layers and from mixed (WR and EBA) loci (see section 3.4 below). For the initial stage of the analysis we preferred to include all the retrieved fan scrapers from both secure and unsecure contexts together, referring to them as one assemblage. Then, the sample was divided into two groups: fan scrapers and 'cortical fan scrapers' (Rosen 1983; 1997; Rosen et al. 2006; Abe 2008). The fan scraper group can be clearly distinguished by a flat cortical dorsal face. We will refer to this group of fan scrapers as the 'flat cortex fan scrapers' (FCFS). The second group includes the rest of the fan scrapers (those with a convex cortical dorsal face and fragmented items with dubious flatness of the dorsal face) and will be referred to as 'cortical fan scrapers' (CFS).This two group separation persists in every techno-typological analysis that was conducted, and the results will be presented separately in order to compare between the two groups.

During analysis of the Ein Zippori lithics we noticed that several items typically defined as burin spalls retain cortex and characteristic dorsal retouch, similar to the cortex and retouch characterizing fan scrapers. We suggest that these spalls were most probably removed from fan scraper lateral edges (see below in section 3.5, and Yerkes et al. 2016). Fan scraper spalls have not yet been clearly defined in the literature, and those from Megiddo (Shimelmintz \& Adams 2014) technologically differ from the spalls presented here. However, we define fan scraper spalls as thin (in the case of Ein Zippori $1 \mathrm{~cm}$ mean thickness, with min. $0.5 \mathrm{~cm}$ and max. $1.5 \mathrm{~cm}$ ) and mostly cortical and elongated flaked items with two ventral faces intersecting at a nearly 90 degree angle and scraper retouch on the lateral edge opposed to the actual ventral face of the item.

Fan scrapers and spalls were analyzed according to raw material characteristics, blank type, metrics and the location of retouch as follows: Blank type categories include cortical and non-cortical flakes and blades, or tabular flint (in most cases flat and thin flint slabs). Raw material types were defined by Lucy Wilson and Aviad Agam following an analysis of raw material types from different areas and layers of the site (see below). Metric categories include maximum length, width and thickness of the items according to the flaking axes. We present the metric analysis of complete tools and spalls only. Maximum thickness of every working edge of fan scrapers and spalls was measured in the thickest point of the retouch. Angles of every working edge were measured with a goniometer at three different points on the working edge, since in most cases the edges exhibit an uneven angle along the same edge. Afterwards, mean angle was calculated per each edge including all the measurements. We documented the location of the retouch - dorsal, ventral, or bifacial.

The data presented here consists of a sample of $\mathrm{N}=191$ fan scrapers and $\mathrm{N}=35$ spalls from all excavated areas of Ein Zippori. The analysis includes observations on raw material, typology, technology, maintenance and recycling.

\subsection{Raw material and tool blanks}

Primary and secondary flint sources are abundant in the immediate vicinity of Ein Zippori. Many of these show knapping waste related to the Middle Palaeolithic (Ekshtain et al. 2012) as well as the Pre Pottery Neolithic periods (Oshri et al. 1999; Garfinkel 2007; 
Barzilai \& Milevski 2015). Our own study of lithic raw materials used at WR and EBA Ein Zippori and the potential sources in the vicinity of the site is in progress (Wilson \& Agam 2016). Thus far, $\mathrm{N}=43$ flint types have been identified within the site's lithic assemblages, labeled alphabetically from A to AQ, by order of classification. Flint type classification was based on visual characteristics, such as variations in color, traits of cortex, sub-cortical layers, any unique patterns (e.g., circles, stripes, spots, etc.), degrees of homogeneity and of translucency, presence of impurities, any visible fossils, etc. Types A, B, C, D and F are by far the most frequent types accounting for $92.6 \%$ of the sampled items. A field survey in the vicinity of the site shows that the most frequent flint types on-site (A, B, C, D and F) are highly abundant in very close proximity to the site (starting from $100 \mathrm{~m}$ and up to $2 \mathrm{~km}$.). Furthermore, it appears that types A, B, C, D and F can be grouped, as they are most likely variations of very similar raw material types.

The vast majority of the examined fan scrapers (93\%) and spalls (92\%) are made from this group of flint types. However, FCFS differ from CFS in raw material selection (Figure 2) and while $52.8 \%$ of FCFS were made of flint type D, and $8.3 \%$ of flint type J, for CFS, type D and $\mathrm{J}$ comprise only $14.4 \%$ and $0.8 \%$ respectively (Table 1 , Figure 3 ). Type D is a coarsegrained dark brown flint (see figures in section 3.5). Type $\mathrm{J}$ is a coarse-grained very dark brown (almost black) flint. On the contrary types A and B flint are coarse-grained light-brown (see figures in sections 3.5 and 3.6). Flint type D is found in abundance in close proximity to Ein Zippori, however the nodules that were found in our survey were relatively small, and, as was already mentioned, not homogenous (contained a combination of several flint types on the same nodule). We didn't find large type D nodules with flat cortex that could be suitable for the production of FCFS. Moreover, we didn't find large nodules with flat cortex, of any flint type. Type $\mathbf{J}$ raw material wasn't detected in our survey and may likely not be a local type, but the limitations of present day surveys in reflecting past availability should be born in mind. Apparently, many of the FCFS were not locally produced but rather brought to the site from elsewhere.

Table 1. Fan scrapers and spalls raw material types, Ein Zippori

\begin{tabular}{lllllll}
\hline RM type & FCFS \# & FCFS \% & CFS \# & CFS \% & Spalls \# & Spalls \% \\
\hline A, B, C & 13 & $36.1 \%$ & 98 & $78.4 \%$ & 22 & $81.5 \%$ \\
D & 19 & $52.8 \%$ & 18 & $14.4 \%$ & 3 & $11.1 \%$ \\
J & 3 & $8.3 \%$ & 1 & $0.8 \%$ & 0 & $0.0 \%$ \\
Other & 1 & $2.8 \%$ & 8 & $6.4 \%$ & 2 & $7.4 \%$ \\
\hline Total & $\mathbf{3 6}$ & $\mathbf{1 0 0 . 0 \%}$ & $\mathbf{1 2 5}$ & $\mathbf{1 0 0 . 0 \%}$ & $\mathbf{2 7}$ & $\mathbf{1 0 0 . 0 \%}$ \\
\hline
\end{tabular}

In general, most fan scrapers and spalls were manufactured on cortical flakes and blades, but tabular flint and non-cortical flakes were also used in small numbers (see sections 3.2 and 3.3 below). FCFS were manufactured on blades as frequently as on flakes, while CFSs were made mainly on flakes. All FCFS retain a cortical dorsal face, while $8 \%$ of the CFS do not retain cortex. Cortex is present to a minor extent in the spalls, likely due to the nature of spall reduction - a burination of a thin strip of the working edge of the tool where cortex is less frequent. Cores for the production of fan scraper blanks (see Fujii 1998-2001; Quintero et al. 2002) were not recovered at Ein Zippori. 

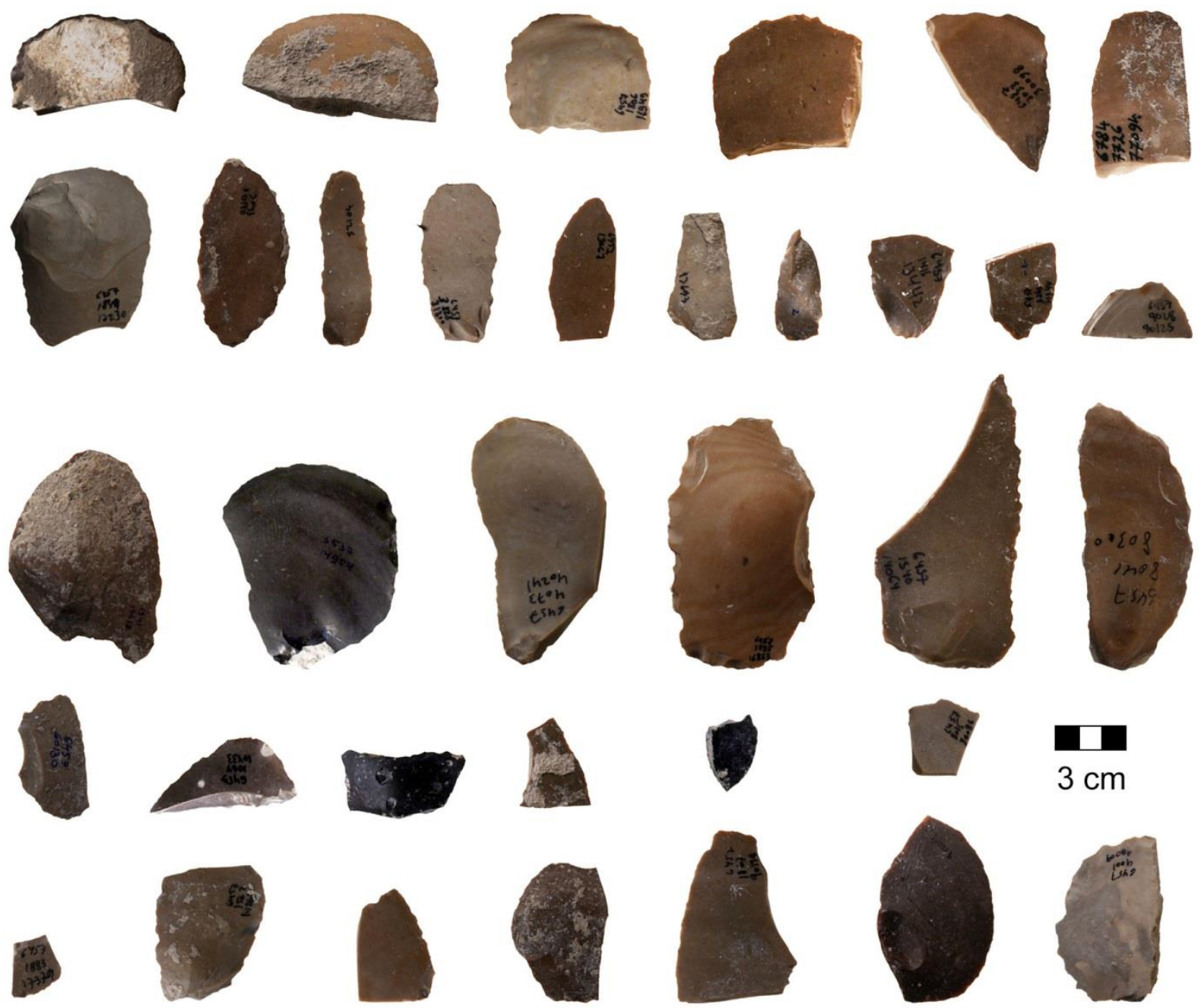

Figure 2. Predominance of dark raw material types. Ventral faces of FCFS, Ein Zippori

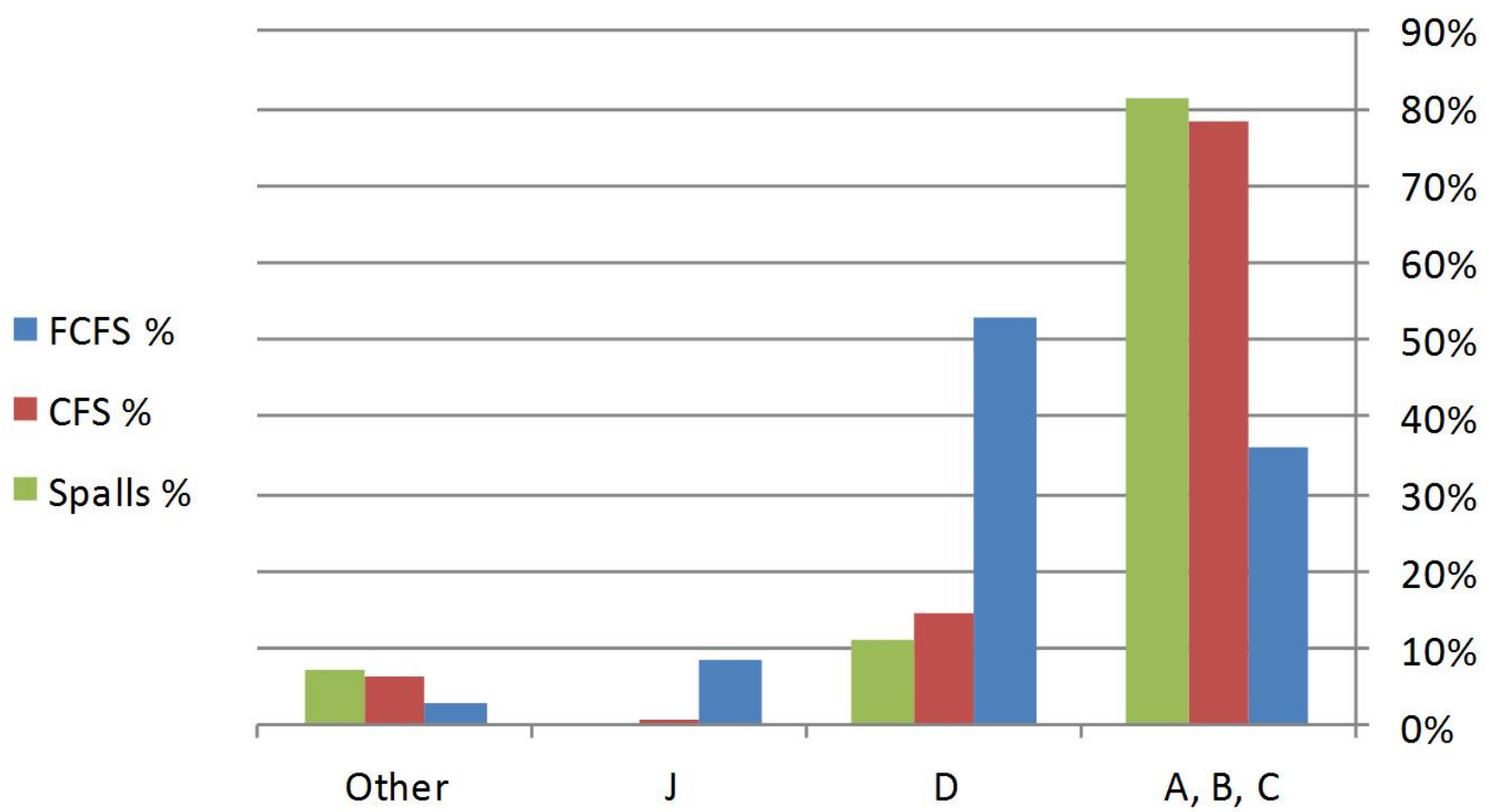

Figure 3. Fan scrapers and spalls raw material types, Ein Zippori. A graphical presentation of Table 1. 


\subsection{Typology}

A metric method (a ratio of length to width after Rosen 1983; 1997: 71) was applied for typological definition of the Ein Zippori fan scrapers (Table 2). Severely broken items (fragments) were not included in the typological analysis. When the shape of a fan scraper fragment could be predicted with high certainty, it was typologically defined and counted accordingly. Four types were defined (see figures in section 3.5):

- Elongated fan scrapers - a length to width ratio $>2$.

- Oval fan scrapers - a length to width ratio varying between 1.11 and 1.99 .

- Round fan scrapers - a length to width ratio of $1: 1$, with a $10 \%$ margin $(0.9-1.1)$.

- Fan shaped fan scrapers - a length to width ratio of less than 0.89 .

Typological differences between the two groups are of note (Table 2, Figure 4). While the elongated type is the most frequent type in FCFS, it is the least frequent type in CFS. The round type is absent from the FCFSs, and the fan shaped type is much less frequent in FCFSs than in CFSs. Oval shaped fan scrapers are frequent in both groups. Additionally, remarkable differences in metrical properties can be traced when both groups are compared (Table 3). FCFSs tend to be on average $2 \mathrm{~cm}$ longer and $0.4 \mathrm{~cm}$ thinner than CFSs. The average length to thickness (L:T) ratio is almost two times larger in FCFS.

Table 2. Fan scrapers typological division, Ein Zippori

\begin{tabular}{lllll}
\hline Type & FCFS \# & FCFS \% & CFS \# & CFS \% \\
\hline Elongated & 9 & $24 \%$ & 4 & $3 \%$ \\
Oval & 8 & $22 \%$ & 51 & $33 \%$ \\
Round & 0 & $0 \%$ & 24 & $16 \%$ \\
Fan & 3 & $8 \%$ & 28 & $18 \%$ \\
Irregular & 0 & $0 \%$ & 3 & $\mathbf{2 \%}$ \\
Fragments & 17 & $46 \%$ & 44 & $\mathbf{2 9 \%}$ \\
\hline Total & $\mathbf{3 7}$ & $\mathbf{1 0 0 \%}$ & $\mathbf{1 5 4}$ & $\mathbf{1 0 0 \%}$ \\
\hline
\end{tabular}

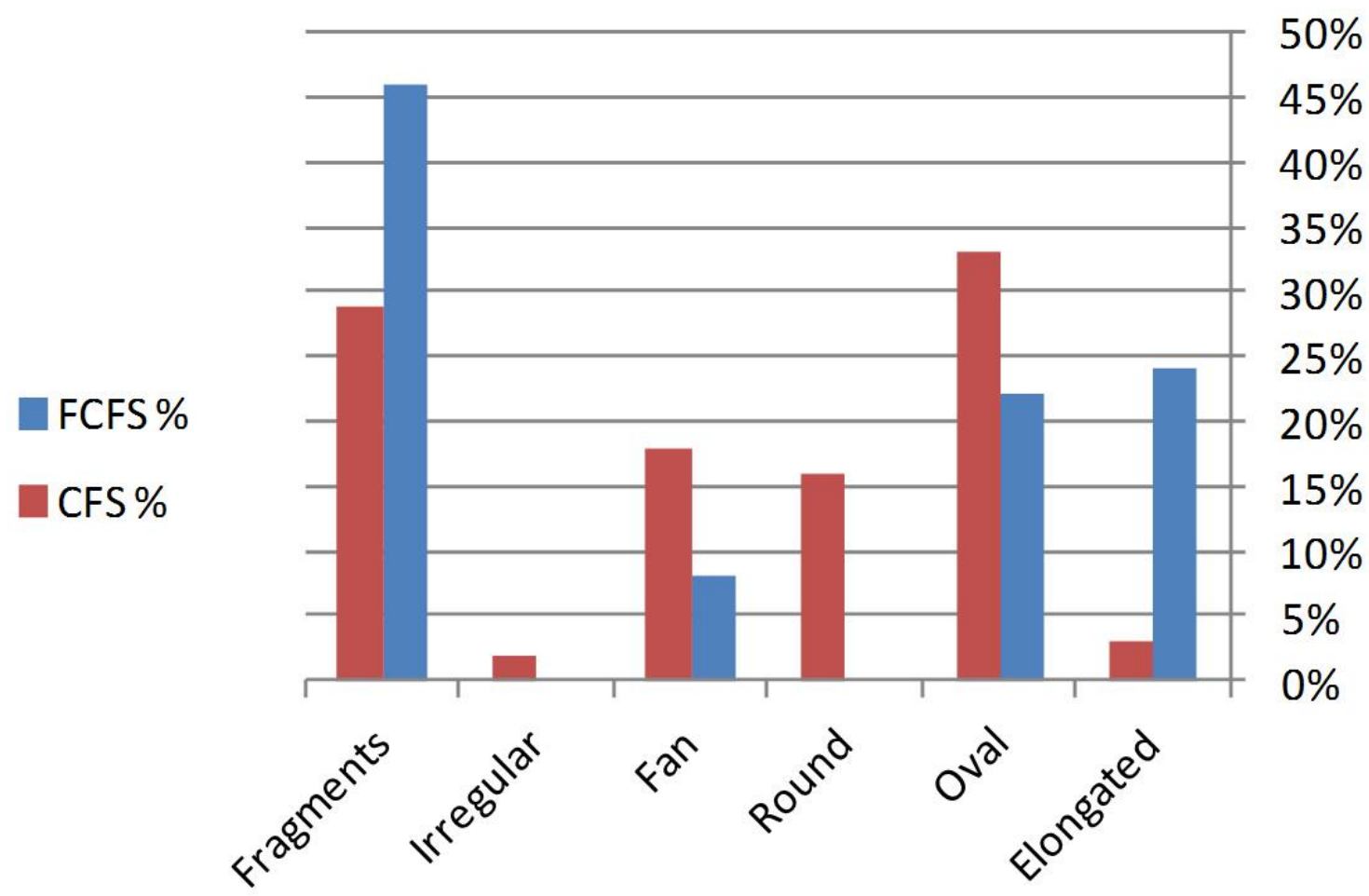

Figure 4. Fan scrapers typological division, Ein Zippori. A graphical presentation of Table 2. 
Table 3. Fan scrapers metrical properties in $\mathrm{cm}$, with S.D. Abbreviations: Num - number of measured fan scrapers (respectively); L - length; W - width; T - thickness

\begin{tabular}{|c|c|c|c|c|c|c|c|}
\hline \multirow[b]{2}{*}{ Type } & & \multirow[b]{2}{*}{ Num } & \multirow[b]{2}{*}{$\begin{array}{c}\text { Average } \\
\text { L }\end{array}$} & \multirow[b]{2}{*}{$\begin{array}{c}\text { Average } \\
\text { W }\end{array}$} & \multicolumn{3}{|c|}{ Average } \\
\hline & & & & & Average T & $\begin{array}{l}\mathrm{L}: \mathrm{W} \\
\text { ratio }\end{array}$ & $\begin{array}{l}\text { Average } \\
\text { L:T ratio }\end{array}$ \\
\hline \multirow[t]{2}{*}{ Elongated } & FCFS & $7,9,9$ & $\begin{array}{c}8.8 \\
( \pm 2.2)\end{array}$ & $\begin{array}{c}3.7 \\
( \pm 1.2)\end{array}$ & $\begin{array}{c}1.0 \\
( \pm 0.2)\end{array}$ & 2.4 & 8.8 \\
\hline & CFS & $4,4,4$ & $\begin{array}{c}6.6 \\
( \pm 1.2)\end{array}$ & $\begin{array}{c}3.2 \\
( \pm 0.7)\end{array}$ & $\begin{array}{c}1.1 \\
( \pm 0.1)\end{array}$ & 2.1 & 6.0 \\
\hline \multirow[t]{2}{*}{ Oval } & FCFS & $4,5,8$ & $\begin{array}{c}8.4 \\
( \pm 1.0)\end{array}$ & $\begin{array}{c}5.9 \\
( \pm 1.0)\end{array}$ & $\begin{array}{c}1.1 \\
( \pm 0.2)\end{array}$ & 1.4 & 7.6 \\
\hline & CFS & $41,41,51$ & $\begin{array}{c}7.2 \\
( \pm 1.6)\end{array}$ & $\begin{array}{c}5.1 \\
( \pm 1.2)\end{array}$ & $\begin{array}{c}1.4 \\
( \pm 0.3)\end{array}$ & 1.4 & 5.1 \\
\hline \multirow[t]{2}{*}{ Round } & FCFS & non & -- & -- & -- & -- & -- \\
\hline & CFS & $24,24,24$ & $\begin{array}{c}5.5 \\
( \pm 0.9)\end{array}$ & $\begin{array}{c}5.6 \\
( \pm 0.9)\end{array}$ & $\begin{array}{c}1.6 \\
( \pm 0.4)\end{array}$ & 1.0 & 3.4 \\
\hline \multirow[t]{2}{*}{ Fan } & FCFS & $3,3,3$ & $\begin{array}{c}6.6 \\
( \pm 1.2)\end{array}$ & $\begin{array}{c}8.7 \\
( \pm 1.0)\end{array}$ & $\begin{array}{c}1.7 \\
( \pm 0.4)\end{array}$ & 0.8 & 3.9 \\
\hline & CFS & $27,27,28$ & $\begin{array}{c}5.8 \\
( \pm 1.5)\end{array}$ & $\begin{array}{c}7.0 \\
( \pm 1.4)\end{array}$ & $\begin{array}{c}1.7 \\
( \pm 0.5)\end{array}$ & 0.8 & 3.4 \\
\hline \multirow[t]{2}{*}{ Irregular } & FCFS & none & -- & -- & -- & -- & -- \\
\hline & CFS & $2,2,3$ & $\begin{array}{c}6.1 \\
( \pm 0.1)\end{array}$ & $\begin{array}{c}6.6 \\
( \pm 0.3)\end{array}$ & $\begin{array}{c}1.5 \\
( \pm 0.2)\end{array}$ & 0.9 & 4.1 \\
\hline \multirow[t]{2}{*}{ Fragments } & FCFS & $0,0,17$ & -- & -- & $\begin{array}{c}0.8 \\
( \pm 0.3)\end{array}$ & -- & -- \\
\hline & CFS & $0,0,44$ & -- & -- & $\begin{array}{c}1.1 \\
( \pm 0.3)\end{array}$ & -- & -- \\
\hline \multirow[t]{2}{*}{ Total } & FCFS & $14,17,37$ & $\begin{array}{c}8.2 \\
( \pm 1.9)\end{array}$ & $\begin{array}{c}5.3 \\
( \pm 2.2)\end{array}$ & $\begin{array}{c}1.0 \\
( \pm 0.4)\end{array}$ & 1.5 & 8.2 \\
\hline & CFS & $99,99,154$ & $\begin{array}{c}6.3 \\
( \pm 1.6)\end{array}$ & $\begin{array}{c}5.7 \\
( \pm 1.5)\end{array}$ & $\begin{array}{c}1.4 \\
( \pm 0.4)\end{array}$ & 1.1 & 4.5 \\
\hline
\end{tabular}

\subsection{Technology}

FCFS are characterized by a flat dorsal face and an even blank thickness for all of its length (89\% of FCFS). On the contrary, CFS exhibit uneven thickness of the blank. Platform preparation was more frequent in FCFS (57\%) than CFS (29\%) (Table 4). Grinding of the cortex is difficult to detect due to a cover of incrustation on top of many of the scrapers. However, both groups exhibit a low proportion of 'ground cortex' fan scrapers. Incisions of geometric patterns were detected on two fan scrapers only (see the figures in section 3.5), both are FCFS. One of the incised fan scrapers was made on a very thin flint nodule and the incisions are present on both cortical faces. No bulb thinning was observed in either group. Fan scrapers of both groups have three retouched (working) edges on average (see below for the detailed retouch analysis).

In both groups of fan scrapers as well as spalls, retouch is mainly on the dorsal face (Table 5). Bifacially retouched items are rarely present and are only partially bifacially retouched (one edge or a portion of an edge). Tables 6 and 7, and Figure 5 present the average thickness and angle of the retouched edges of Ein Zippori fan scrapers. Retouched edges of fragmented fan scrapers and of spalls are presented as well. It is apparent that lateral edges 
and distal ends were retouched frequently while retouched proximal ends are rare. In most of the cases proximal end retouch removes the bulb of percussion, and apparently is steeper than retouch on lateral edges and the distal ends.

Table 4. Technological traits of fan scrapers, Ein Zippori

\begin{tabular}{lcccc}
\hline Technological traits & FCFS \# & FCFS \% & CFS \# & CFS \% \\
\hline Even thickness of the blank & 33 & $89 \%$ & 0 & $0 \%$ \\
Platform preparation & 8 (of 14) & $57 \%$ & 22 (of 76) & $29 \%$ \\
Bulb thinning & 0 & $0 \%$ & 1 & $1 \%$ \\
Ground cortex & 3 & $8 \%$ & 2 & $1 \%$ \\
Incisions on cortex & 2 & $5 \%$ & 0 & $0 \%$ \\
Number of retouched edges - complete tools only & $3(2.91)$ & & $3(2.84)$ & \\
\hline
\end{tabular}

Table 5. Blanks, cortex and retouch location of fan scrapers and spalls, Ein Zippori. Abbreviations: unk unknown.

\begin{tabular}{llcccccc}
\hline & & FCFS \# & FCFS \% & CFS \# & CFS \% & Spalls \# & Spalls \% \\
\hline Blanks & Flake & 10 & $27 \%$ & 96 & $62 \%$ & unk & unk \\
& Blade & 9 & $24 \%$ & 4 & $3 \%$ & unk & unk \\
& Flake or Blade & 17 & $46 \%$ & 41 & $27 \%$ & 31 & $89 \%$ \\
& Tabular & 1 & $3 \%$ & 13 & $8 \%$ & 4 & $11 \%$ \\
& Total & 37 & $100 \%$ & 154 & $100 \%$ & 35 & $100 \%$ \\
\hline Cortex present & & 37 & $100 \%$ & 141 & $92 \%$ & 27 & $77 \%$ \\
\hline Retouch position & Dorsal & 36 & $97 \%$ & 147 & $95 \%$ & 34 & $97 \%$ \\
& Bifacial & 1 & $3 \%$ & 7 & $5 \%$ & 1 & $3 \%$ \\
& Total & 37 & $100 \%$ & 154 & $100 \%$ & 35 & $100 \%$ \\
\hline
\end{tabular}

Table 6. Mean thickness (in cm) of the fan scrapers' and spalls' retouched working edges, Ein Zippori.

\begin{tabular}{|c|c|c|c|c|c|}
\hline Type & & $\begin{array}{c}\text { Number of measured } \\
\text { fan scrapers }\end{array}$ & $\begin{array}{c}\text { Lateral edges } \\
\text { thickness } \\
\end{array}$ & $\begin{array}{c}\text { Distal ends } \\
\text { thickness }\end{array}$ & $\begin{array}{c}\text { Proximal ends } \\
\text { thickness }\end{array}$ \\
\hline \multirow[t]{2}{*}{ Elongated } & FCFS & 9 & $0.8( \pm 0.2)$ & $0.6( \pm 0.1)$ & $0.8( \pm 0.1)$ \\
\hline & CFS & 4 & $0.5( \pm 0.1)$ & $0.5( \pm 0.0)$ & $0.7( \pm 0.0)$ \\
\hline \multirow[t]{2}{*}{ Oval } & FCFS & 8 & $0.6( \pm 0.2)$ & $0.6( \pm 0.2)$ & -- \\
\hline & CFS & 51 & $0.8( \pm 0.3)$ & $0.7( \pm 0.3)$ & $0.8( \pm 0.4)$ \\
\hline \multirow[t]{2}{*}{ Round } & FCFS & 0 & -- & -- & -- \\
\hline & CFS & 24 & $0.8( \pm 0.4)$ & $0.9( \pm 0.3)$ & $1.0( \pm 0.3)$ \\
\hline \multirow[t]{2}{*}{ Fan } & FCFS & 3 & $0.7( \pm 0.4)$ & $1.1( \pm 0.6)$ & -- \\
\hline & CFS & 28 & $0.7( \pm 0.3)$ & $0.8( \pm 0.3)$ & $0.8( \pm 0.4)$ \\
\hline \multirow[t]{2}{*}{ Irregular } & FCFS & 0 & -- & -- & -- \\
\hline & CFS & 3 & $0.8( \pm 0.2)$ & $0.5( \pm 0.0)$ & -- \\
\hline \multirow[t]{2}{*}{ Fragments } & FCFS & 17 & $0.6( \pm 0.2)$ & -- & -- \\
\hline & CFS & 44 & $0.7( \pm 0.3)$ & -- & -- \\
\hline Spalls & & 35 & $0.8( \pm 0.3)$ & -- & -- \\
\hline
\end{tabular}


Table 7. A breakdown of fan scrapers' retouched edges according to angles, Ein Zippori.

\begin{tabular}{llccccccc}
\hline & & $\mathbf{4 0}$ & $\mathbf{4 1 - 5 0}$ & $\mathbf{5 1 - 6 0}$ & $\mathbf{6 1 - 7 0}$ & $\mathbf{7 1 - 8 0}$ & $\mathbf{8 1}$ & Total \\
\hline FCFS & Lateral \# & 1 & 6 & 5 & 16 & 6 & 1 & 35 \\
& Lateral \% & $2.9 \%$ & $17.1 \%$ & $14.3 \%$ & $45.7 \%$ & $17.1 \%$ & $2.9 \%$ & $100.0 \%$ \\
& Distal \# & 2 & 1 & 6 & 4 & 2 & 1 & 16 \\
& Distal \% & $12.5 \%$ & $6.3 \%$ & $37.5 \%$ & $25.0 \%$ & $12.5 \%$ & $6.3 \%$ & $100.0 \%$ \\
& Proximal \# & 0 & 0 & 0 & 1 & 1 & 0 & 2 \\
& Proximal \% & $0.0 \%$ & $0.0 \%$ & $0.0 \%$ & $50.0 \%$ & $50.0 \%$ & $0.0 \%$ & $100.0 \%$ \\
& Fragment \# & 2 & 4 & 12 & 11 & 1 & 1 & 31 \\
& Fragment \% & $6.5 \%$ & $12.9 \%$ & $38.7 \%$ & $35.5 \%$ & $3.2 \%$ & $3.2 \%$ & $100.0 \%$ \\
& Total \# & 3 & 7 & 11 & 21 & 9 & 2 & 53 \\
& Total \% & $5.7 \%$ & $13.2 \%$ & $20.8 \%$ & $39.6 \%$ & $17.0 \%$ & $3.8 \%$ & $100.0 \%$ \\
\hline CFS & Lateral \# & 6 & 13 & 57 & 64 & 36 & 9 & 185 \\
& Lateral \% & $3.2 \%$ & $7.0 \%$ & $30.8 \%$ & $34.6 \%$ & $19.5 \%$ & $4.9 \%$ & $100.0 \%$ \\
& Distal \# & 3 & 6 & 23 & 27 & 19 & 9 & 87 \\
& Distal \% & $3.4 \%$ & $6.9 \%$ & $26.4 \%$ & $31.0 \%$ & $21.8 \%$ & $10.3 \%$ & $100.0 \%$ \\
& Proximal \# & 0 & 0 & 5 & 11 & 7 & 5 & 28 \\
& Proximal \% & $0.0 \%$ & $0.0 \%$ & $17.9 \%$ & $39.3 \%$ & $25.0 \%$ & $17.9 \%$ & $100.0 \%$ \\
& Fragment \# & 0 & 7 & 23 & 25 & 11 & 2 & 68 \\
& Fragment \% & $0.0 \%$ & $10.3 \%$ & $33.8 \%$ & $36.8 \%$ & $16.2 \%$ & $2.9 \%$ & $100.0 \%$ \\
& Total \# & 9 & 26 & 108 & 127 & 73 & 25 & 368 \\
& Total \% & $2.4 \%$ & $7.1 \%$ & $29.3 \%$ & $34.5 \%$ & $19.8 \%$ & $6.8 \%$ & $100.0 \%$ \\
\hline Spalls & Total \# & 0 & 2 & 5 & 15 & 11 & 2 & 35 \\
& Total \% & $0.0 \%$ & $5.7 \%$ & $14.3 \%$ & $42.9 \%$ & $31.4 \%$ & $5.7 \%$ & $100.0 \%$ \\
\hline
\end{tabular}

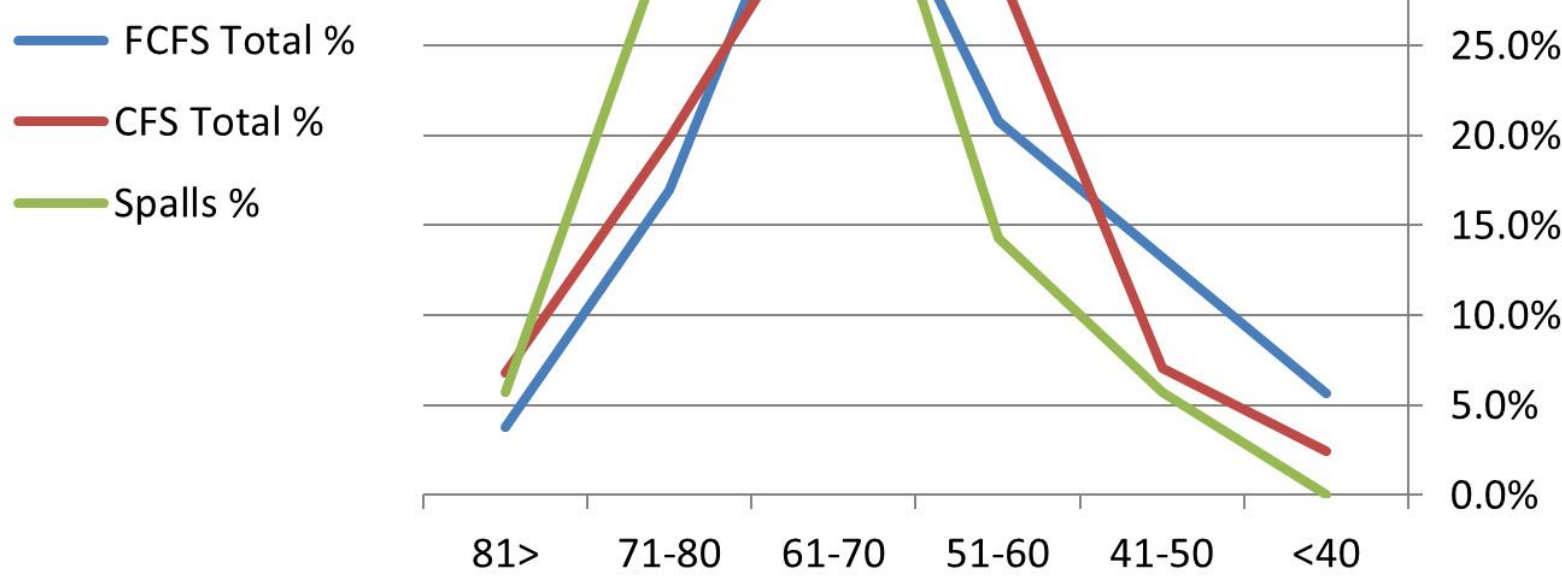

Figure 5. A breakdown of fan scrapers' retouched edges according to angles, Ein Zippori. A graphical representation of Table 7 . 
Considerable variation in edge thickness and angles was observed in each group of fan scrapers as well as in the spalls. Retouched edges properties of fan scrapers and spalls vary from thin to thick and from sharp to abrupt. Most fan scrapers in our sample exhibit considerable variation in edge angles of the different edges of the same tool. We have calculated the minimum and the maximum retouched edge angle of all fan scrapers excluding fragments, and received similar results for both groups. In FCFS, average values of minimum and maximum angles are 52.0 degrees (S.D.10.7), and 76 (S.D.13.4) respectively. In CFS, the average values are 51.2 degrees (S.D. 10.3), and 76.4 (S.D. 12.2) respectively. The results of functional analysis of fan scrapers and spalls (Yerkes et al. 2016) suggest that steeper edges were mostly used for scraping, while sharper edges were used also for cutting. Apparently, this variability in both thickness and angle of the working edges is similar in both groups of fan scrapers. FCFS and CFS cannot be distinguished from one another on the basis of working edges' properties.

In order to clarify the possible reasons for the introduction of fan scrapers in the late PN, Yerkes conducted a pilot examination of five randomly chosen ('not fan') scrapers from the same loci the fan scrapers were retrieved from. The use wear traces found on these scrapers were very similar to those found on fan scrapers (Yerkes et al. 2016). Late PN scrapers (which are not fan scrapers) are predominantly 'end' and 'side' scrapers (e.g., Gopher 1989: 117; Barkai \& Gopher 2012: 837; Khalaily et al. 2015) and this is the case in the late PN layers of Ein Zippori as well. What then is the advantage of fan scrapers? To answer this question we analyzed the techno-typological properties of $\mathrm{N}=40$ randomly selected other ('not fan') scrapers from the same loci as the fan scrapers. 'Side' scrapers in our sample were mostly made on amorphous blanks of varying thickness, size, and morphology, mostly with a single working edge. The morphology of these blanks apparently prevents the production of another working edge that will not result in abrupt retouch, or the possibility of creating any other working edge. Most 'end' scrapers in our sample exhibited one short and abruptly retouched working edge. We propose that the main techno-typological advantage of fan scrapers is their relatively large, mostly flat, thin and homogenous morphology which, compared to most of the other ('not fan') scrapers, permits the creation of several (on average three) relatively long working edges, with various retouched angles from sharp to abrupt on the same tool, and sometimes also on the same working edge.

\subsection{Chronology}

Table 8 summarizes the differences and similarities between late PN, CHG, and EBA fan scrapers based on published accounts, and compares them with CFS vs. FCFS scrapers from Ein Zippori. Post Wadi Rabah and pre Chalcolithic Ghassulian (PoWR-PG) fan scrapers are not presented or discussed here since the samples published from sites assigned to PoWR-PG are small (Epstein 1984; Golan 2006, figs. 27, 28.1,2; Yannai \& Ariel 2006; Dag \& Garfinkel 2007) and since no such layers were clearly identified at Ein Zippori. As can be seen, CFSs from Ein Zippori are quite similar to late PN fan scrapers, while FCFS resemble EBA fan scrapers (see Figures 6-16).

For the comparison presented in Table 8 we have used the following published accounts:

- Late PN (Kaplan 1969; Yeivin \& Olami 1979; Gopher 1989: 199; Golan 2006; Khalaily 2011; Barkai \& Gopher 2012).

- CHG (Rowan \& Levy 1991; Noy 1998; van den Brink et al. 2004; Rowan 2006; Abe 2008).

- EBA (Bar-Yosef et al. 1977; Crowfoot-Payne 1983; Greenhut 1989; Rosen 1993; Marder et al. 1995; Beit-Arie et al. 2003; Abe 2008; Bankirer \& Marder 2003; Milevski 2013 and references therein; Shimelmitz \& Rosen 2014) 
Table 8. Fan scrapers: differences and the similarities through time.

\begin{tabular}{|c|c|c|c|c|c|}
\hline & Late PN & $\begin{array}{l}\text { CFS from Ein } \\
\text { Zippori }\end{array}$ & CHG & EBA & $\begin{array}{l}\text { FCFS from Ein } \\
\text { Zippori }\end{array}$ \\
\hline $\begin{array}{l}\text { Raw } \\
\text { material }\end{array}$ & Local & $\begin{array}{l}\text { Local, coarse- } \\
\text { grained, light } \\
\text { brown cortical } \\
\text { nodules }\end{array}$ & Imported & Imported & $\begin{array}{l}\text { Likely mostly not } \\
\text { local - coarse- } \\
\text { grained, dark } \\
\text { brown to black flat } \\
\text { cortex nodules }\end{array}$ \\
\hline Blank & $\begin{array}{l}\text { Relatively } \\
\text { small and } \\
\text { thick }\end{array}$ & $\begin{array}{l}\text { Relatively } \\
\text { small and } \\
\text { thick, convex } \\
\text { dorsal face }\end{array}$ & $\begin{array}{l}\text { Mostly side- } \\
\text { struck, large } \\
\text { and thin }\end{array}$ & $\begin{array}{l}\text { Mostly end- } \\
\text { struck, large } \\
\text { and thin }\end{array}$ & $\begin{array}{l}\text { Relatively long and } \\
\text { thin, flat dorsal } \\
\text { face, mostly even } \\
\text { thickness. }\end{array}$ \\
\hline Typology & $\begin{array}{l}\text { Mostly oval } \\
\text { and round }\end{array}$ & $\begin{array}{l}\text { mostly oval, } \\
\text { fan, and round }\end{array}$ & $\begin{array}{l}\text { Mostly fan } \\
\text { shaped and } \\
\text { oval }\end{array}$ & $\begin{array}{l}\text { Mostly oval } \\
\text { and } \\
\text { elongated }\end{array}$ & $\begin{array}{l}\text { Mostly elongated } \\
\text { and oval }\end{array}$ \\
\hline $\begin{array}{l}\text { Bulb } \\
\text { thinning }\end{array}$ & Uncommon & Rare & Frequent & Uncommon & None \\
\hline $\begin{array}{l}\text { Retouch } \\
\text { location }\end{array}$ & $\begin{array}{l}\text { Mostly } \\
\text { dorsal, } \\
\text { short }\end{array}$ & $\begin{array}{l}\text { Mostly dorsal, } \\
\text { short }\end{array}$ & $\begin{array}{l}\text { Dorsal and } \\
\text { ventral, } \\
\text { commonly } \\
\text { invasive }\end{array}$ & $\begin{array}{l}\text { Mostly } \\
\text { dorsal, } \\
\text { short }\end{array}$ & $\begin{array}{l}\text { Mostly dorsal, } \\
\text { short }\end{array}$ \\
\hline Incisions & Absent & Absent & Absent & Present & Present \\
\hline $\begin{array}{l}\text { Cortex } \\
\text { grounding }\end{array}$ & $\begin{array}{l}\text { Not } \\
\text { reported }\end{array}$ & Very rare & Rare & Rare & Rare \\
\hline
\end{tabular}

The distribution of the two groups of fan scrapers from Ein Zippori by the stratigraphic units of the site (clean contexts only) presented in Table 9 shows that CFS predominate in WR layers while FCFS predominate in EBA layers. This pattern matches the results from the other sites presented above (Table 8), yet we cannot overlook the presence of a considerable number of FCFS in WR layers, and CFS in EBA layers at Ein Zippori. For instance, both incised fan scrapers (see figures in section 3.5) were retrieved from a clean WR context (following the pottery analysis). Moreover, two other FCFSs were retrieved from the dismantling of a WR floor, and a WR wall. It is noteworthy that published figures of fan scraper profiles, show fan scrapers from Late PN contexts that apparently exhibit a flat dorsal face and an even blank thickness (Kaplan 1969, fig. 12.4; Golan 2006, figs. 28.1,2; Barkai \& Gopher 2012: 838, 839, figs. 19.43.4, 19.44.2). Possible explanations for this are that either FCFS are intrusive in WR layers, or FCFS were indeed present already in the Late PN (to a minor extent). The same logic can be applied to the presence of CFS in EBA layers. They may be intrusive, or some of them may still have been used during the EBA.

Table 9. Breakdown of FCFS and CFS in clean stratigraphic context, Ein Zippori. Percentages according to total fan scrapers in each group (FCFS and CFS).

\begin{tabular}{lllll}
\hline & FCFS \# & FCFS \% & CFS \# & CFS \% \\
\hline EBA & 14 & $60.9 \%$ & 10 & $10.5 \%$ \\
WR & 9 & $39.1 \%$ & 85 & $89.5 \%$ \\
\hline Total & $\mathbf{2 3}$ & $\mathbf{1 0 0 . 0 \%}$ & $\mathbf{9 5}$ & $\mathbf{1 0 0 . 0 \%}$ \\
\hline
\end{tabular}



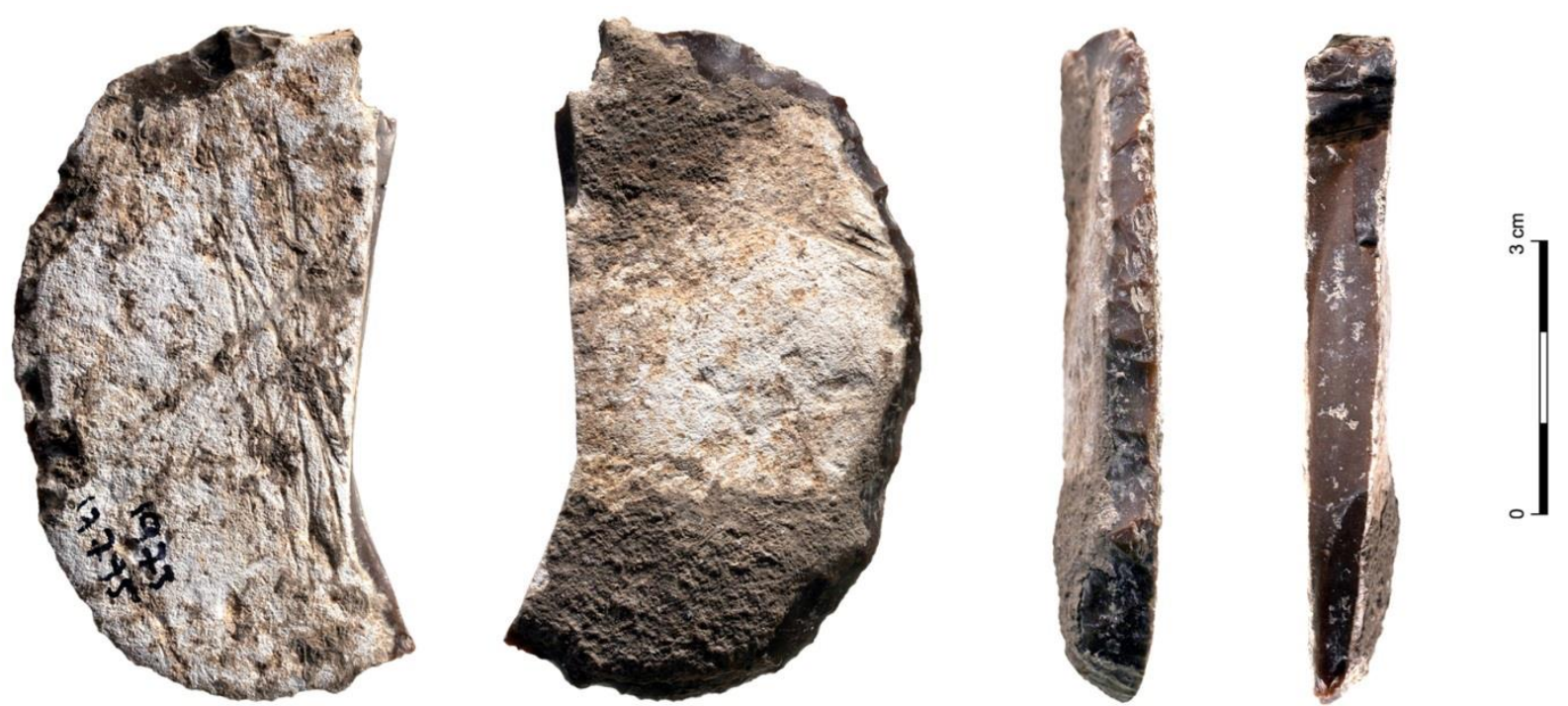

Figure 6. FCFS on tabular type D flint with incisions on both faces, Ein Zippori. Scale bar $=3 \mathrm{~cm}$.
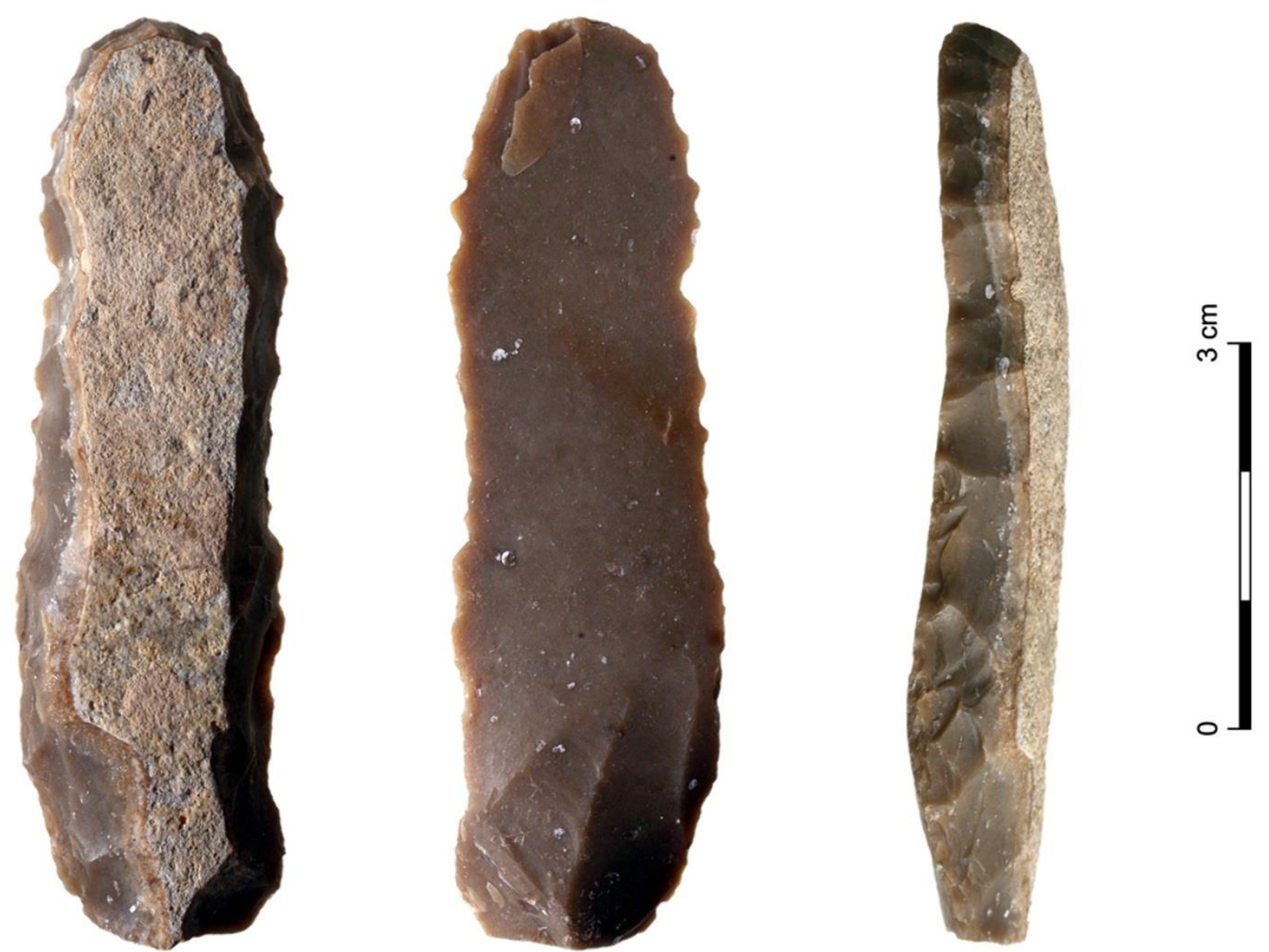

Figure 7. Elongated FCFS, type D flint, Ein Zippori. 

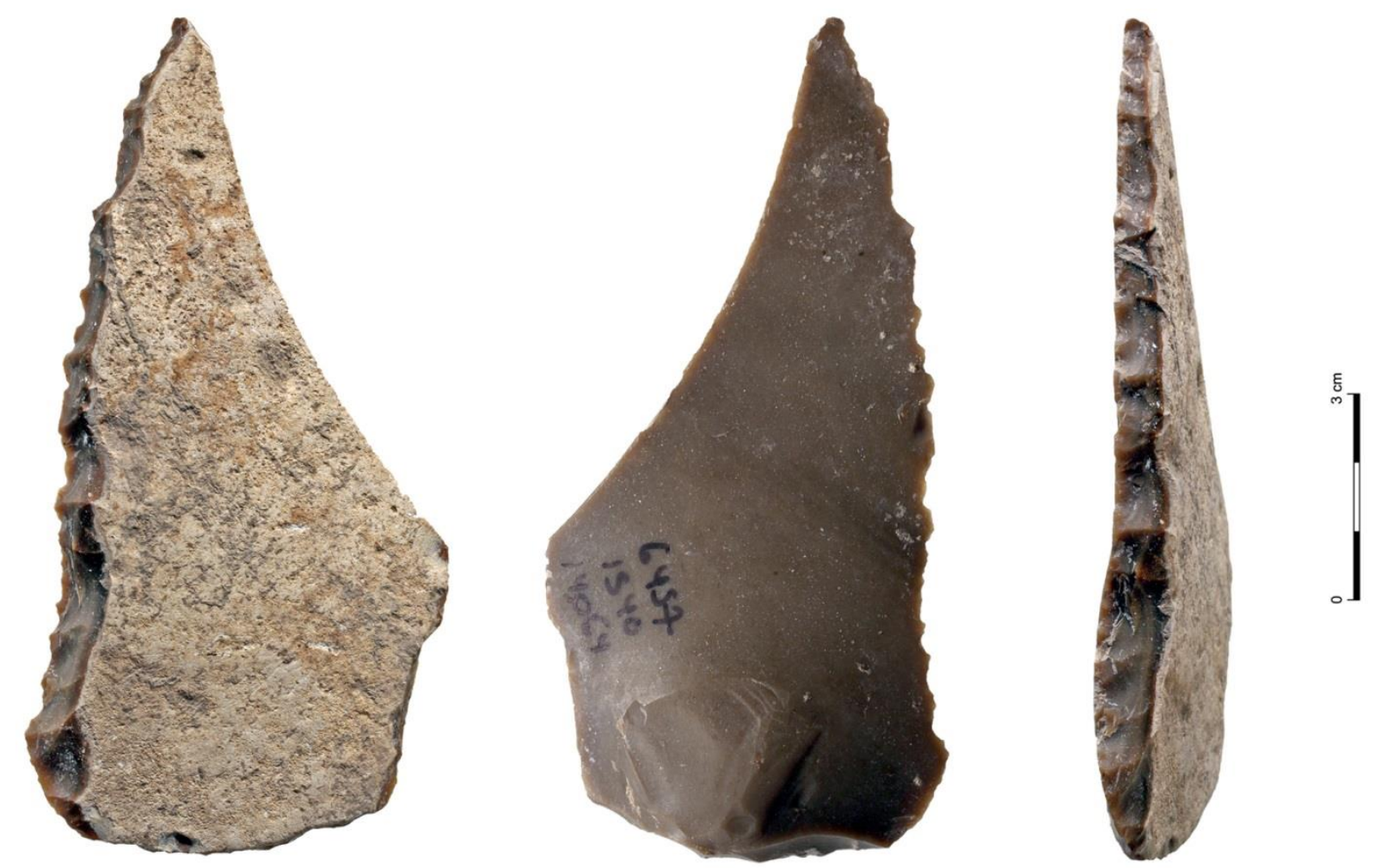

Figure 8. Elongated FCFS, type D flint, Ein Zippori. Scale bar $=3 \mathrm{~cm}$.
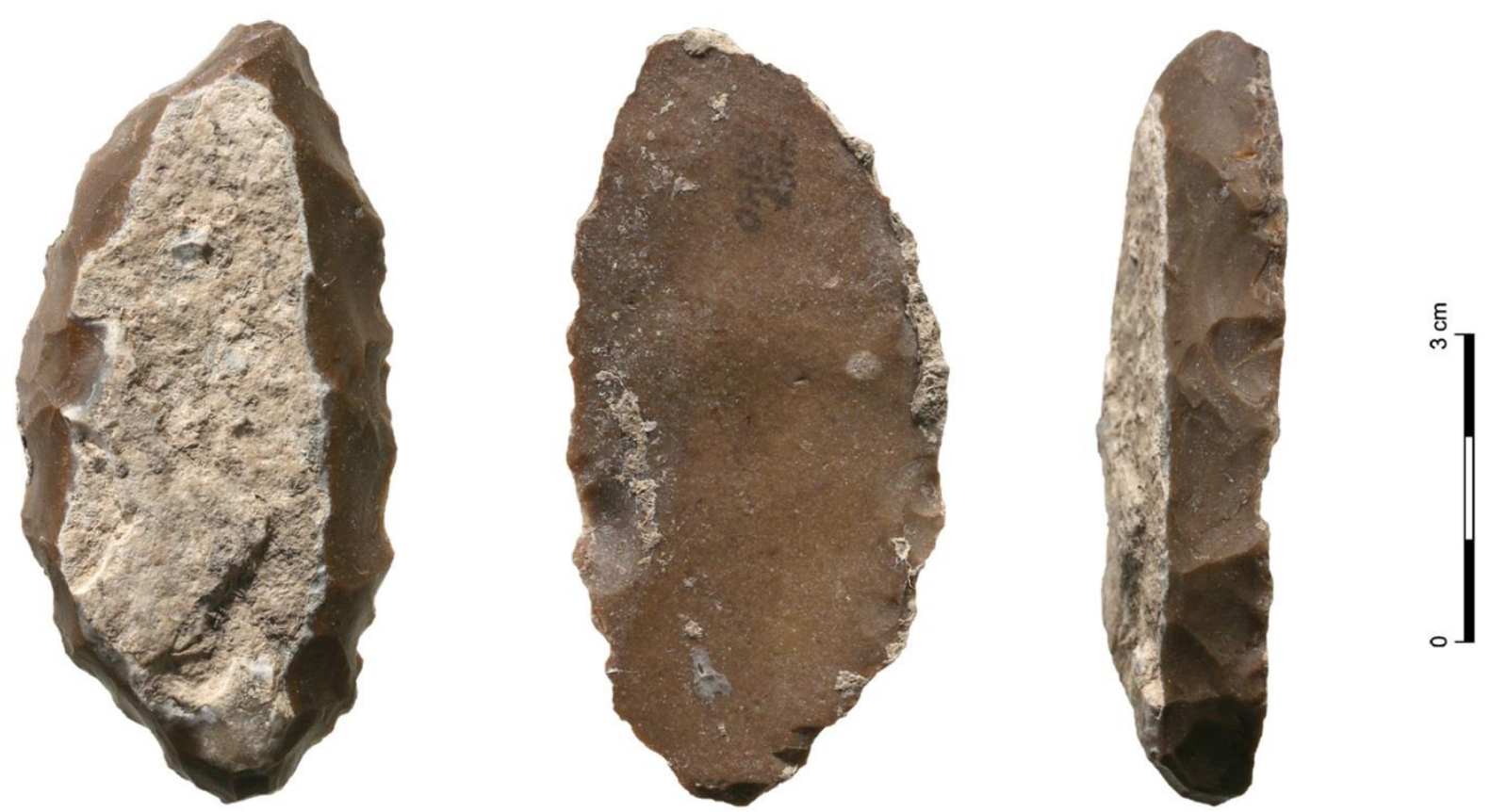

Figure 9. Elongated FCFS, type D flint, Ein Zippori. Scale bar $=3 \mathrm{~cm}$. 

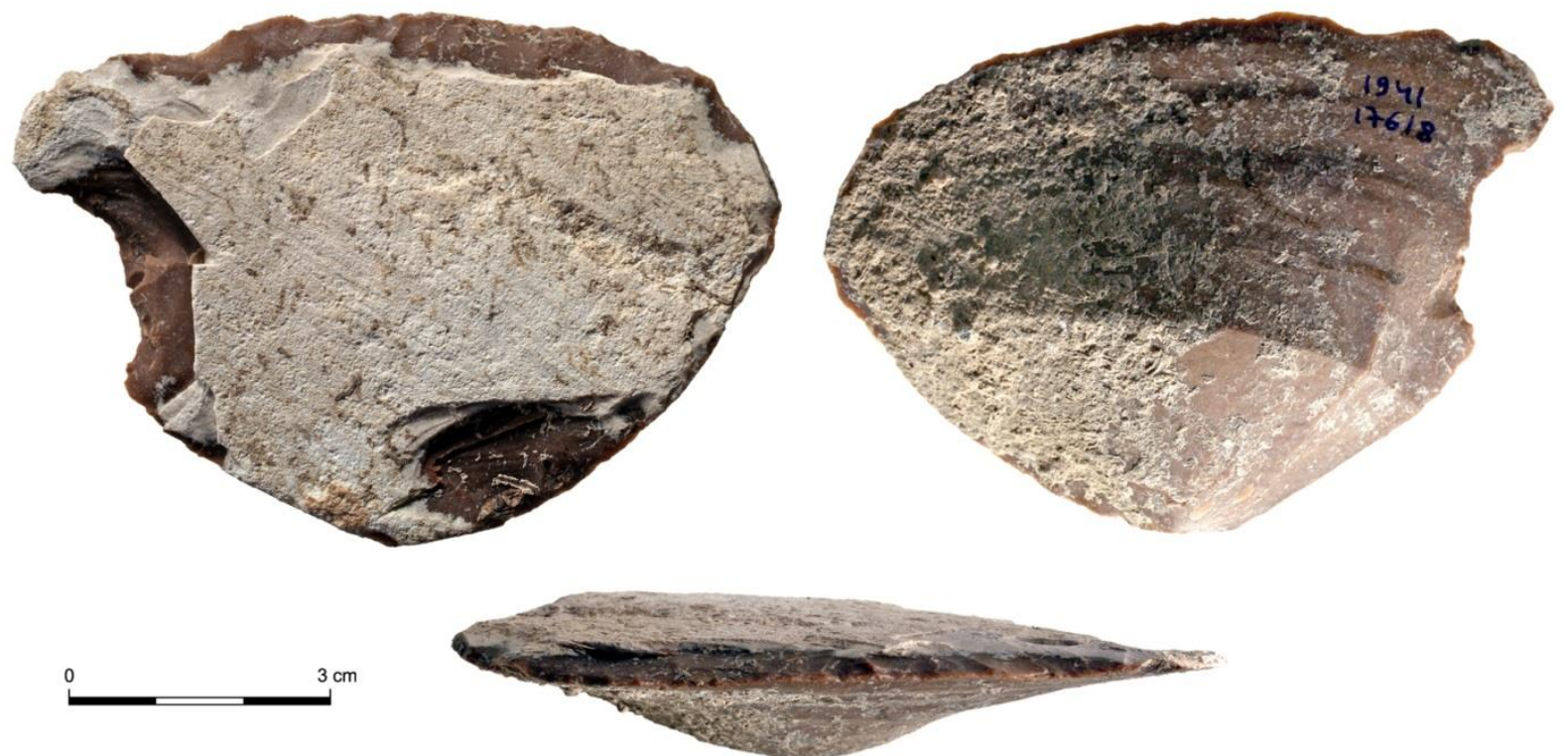

Figure 10. Fan shaped FCFS, type D flint, ground cortex, Ein Zippori. Scale bar $=3 \mathrm{~cm}$.

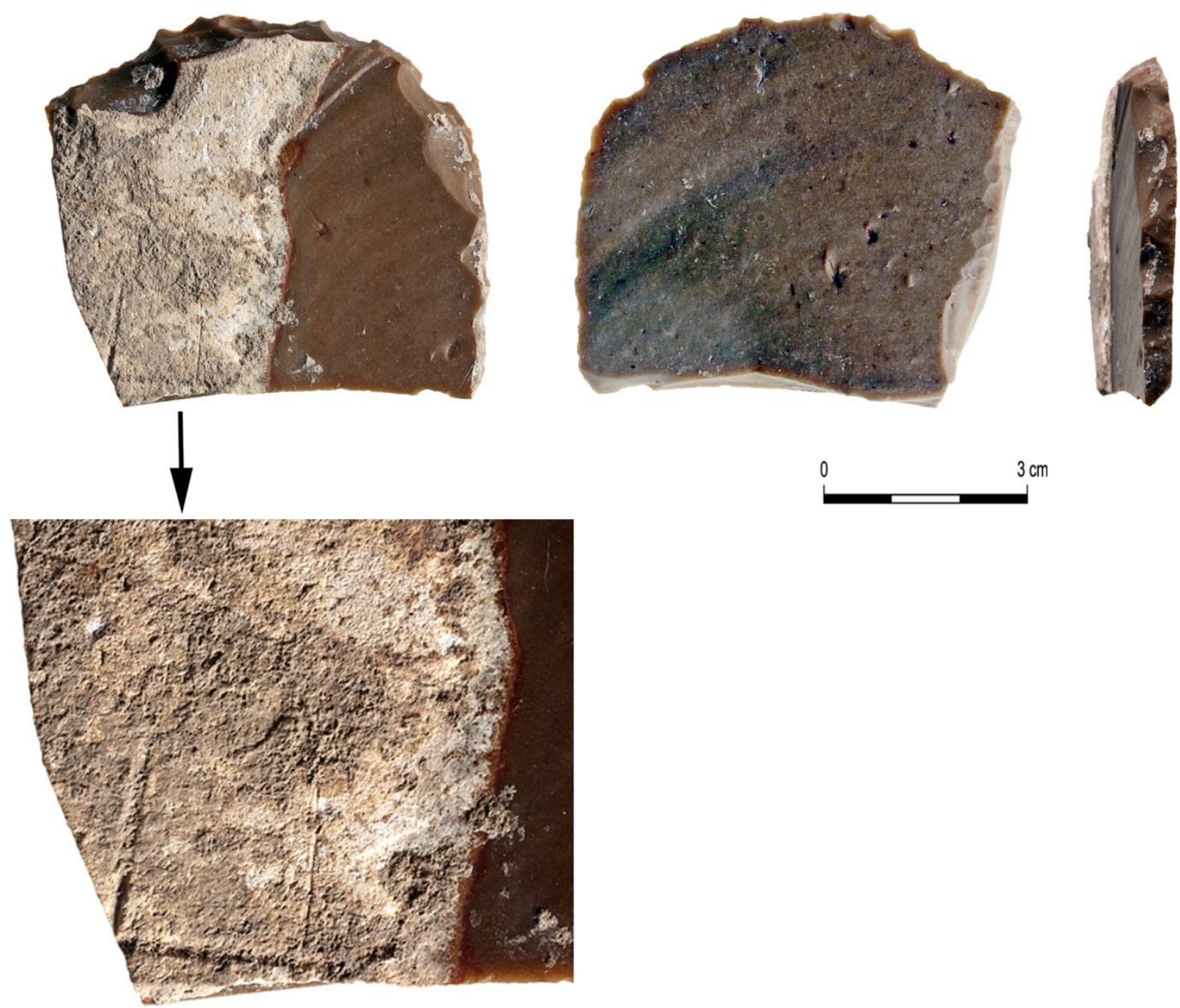

Figure 11. Fragmented FCFS with a geometric incisions on the cortex, type D flint, Ein Zippori. Scale bar = 3 $\mathrm{cm}$. 


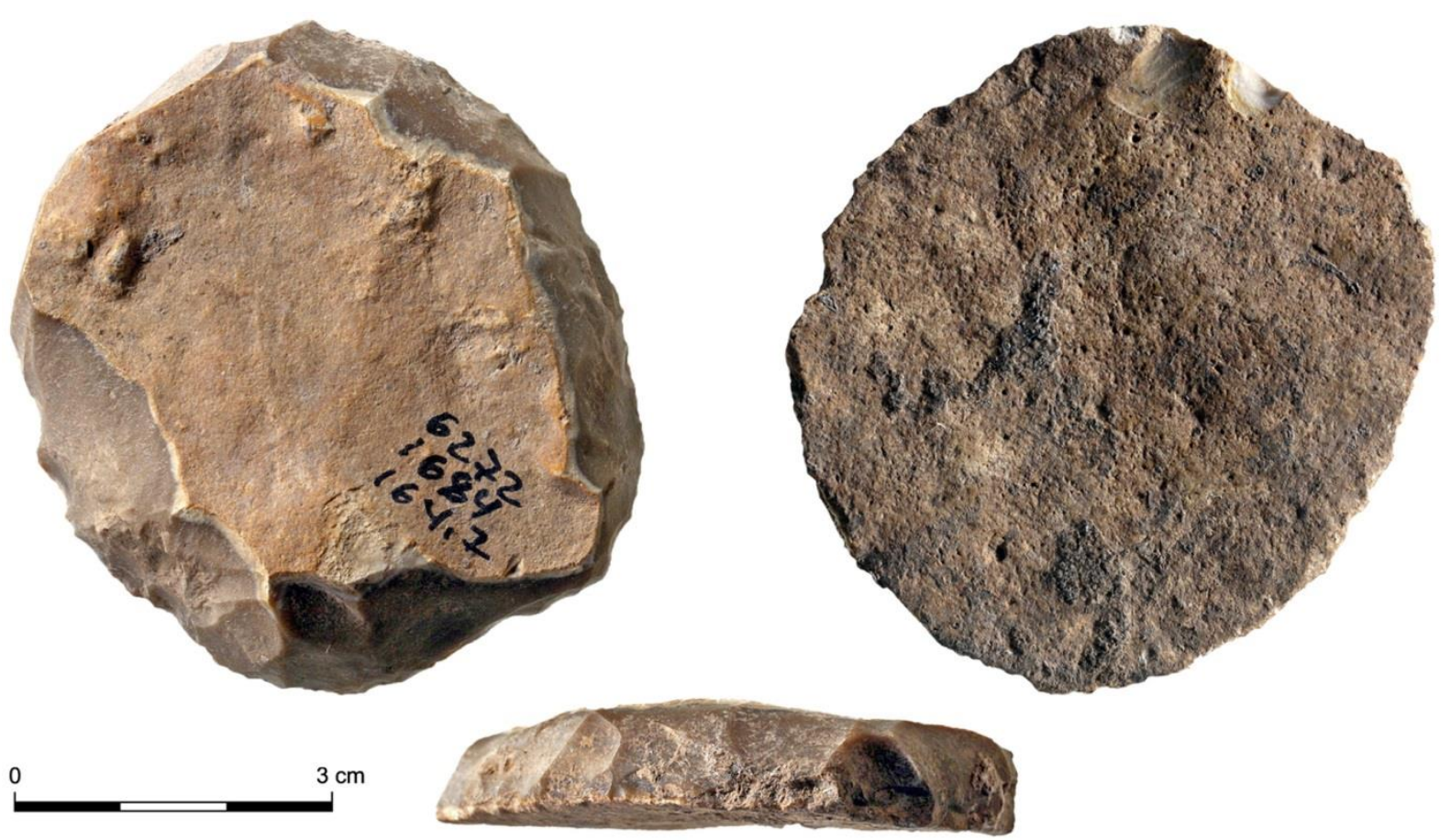

Figure 12. Round CFS, type A flint, Ein Zippori. Scale bar $=3 \mathrm{~cm}$.

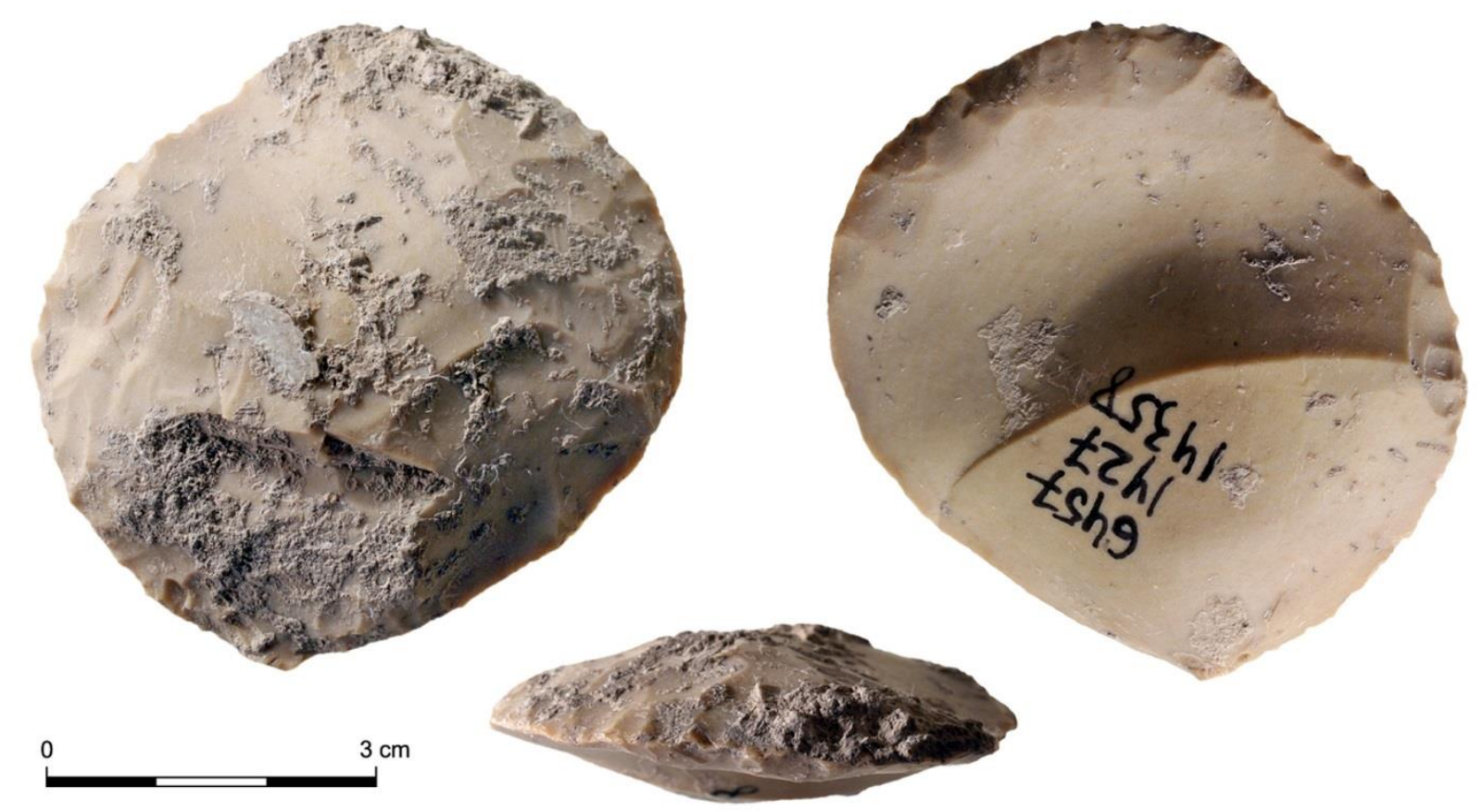

Figure 13. Round CFS, type A flint, Ein Zippori. Scale bar $=3 \mathrm{~cm}$. 

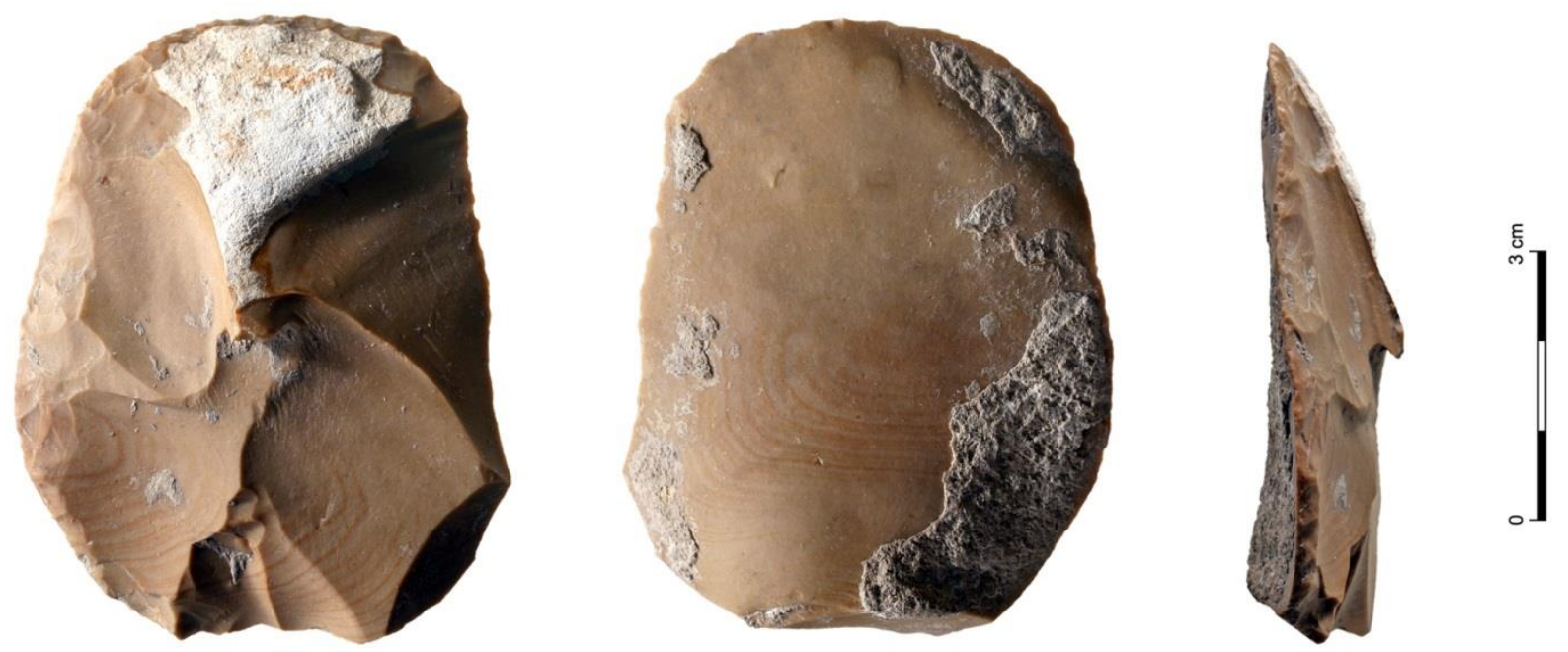

Figure 14. Oval CFS, type A flint. Ein Zippori. Scale bar $=3 \mathrm{~cm}$.
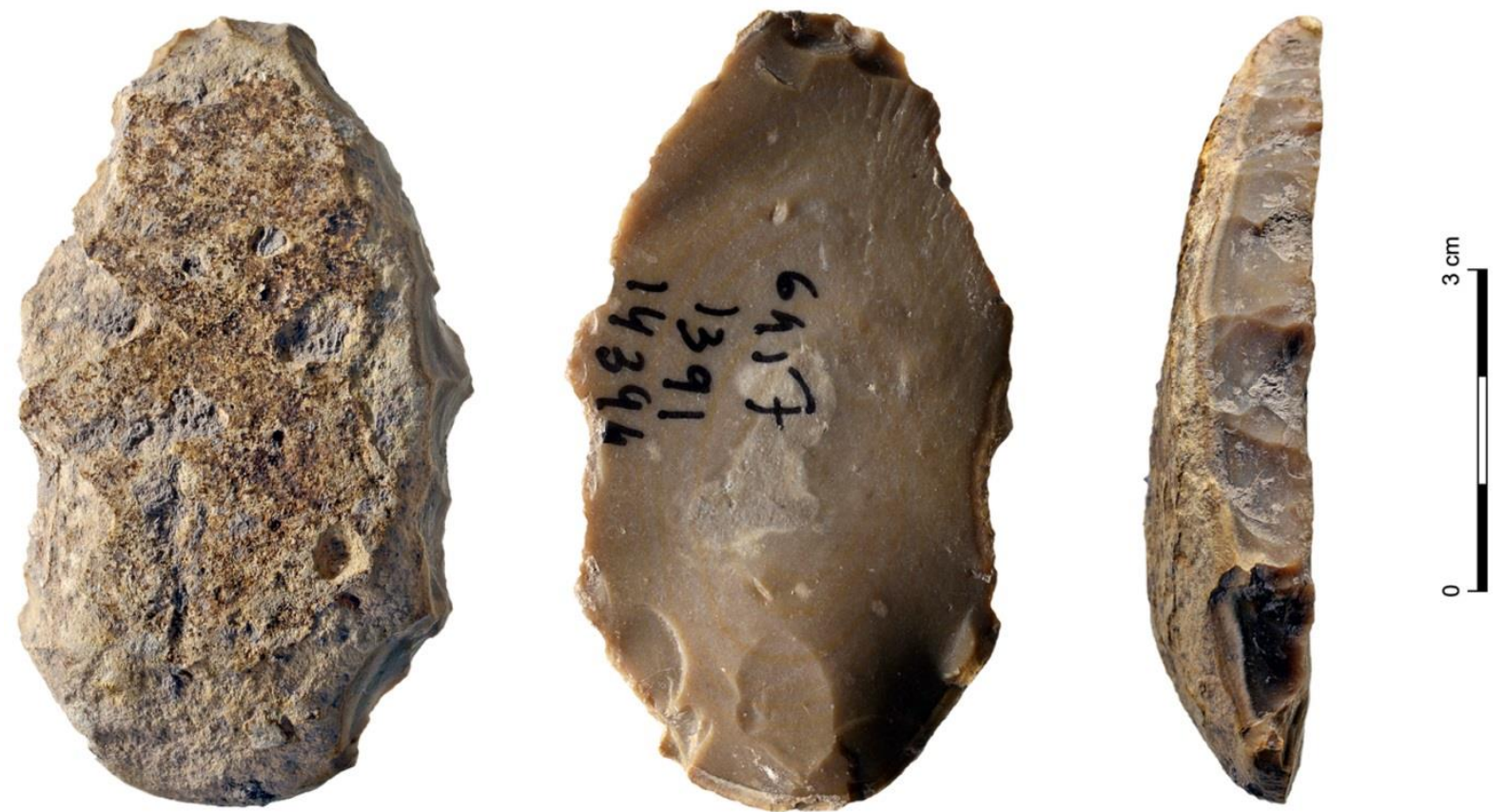

Figure 15. Oval CFS, type B flint, with notches, Ein Zippori. Scale bar $=3 \mathrm{~cm}$.
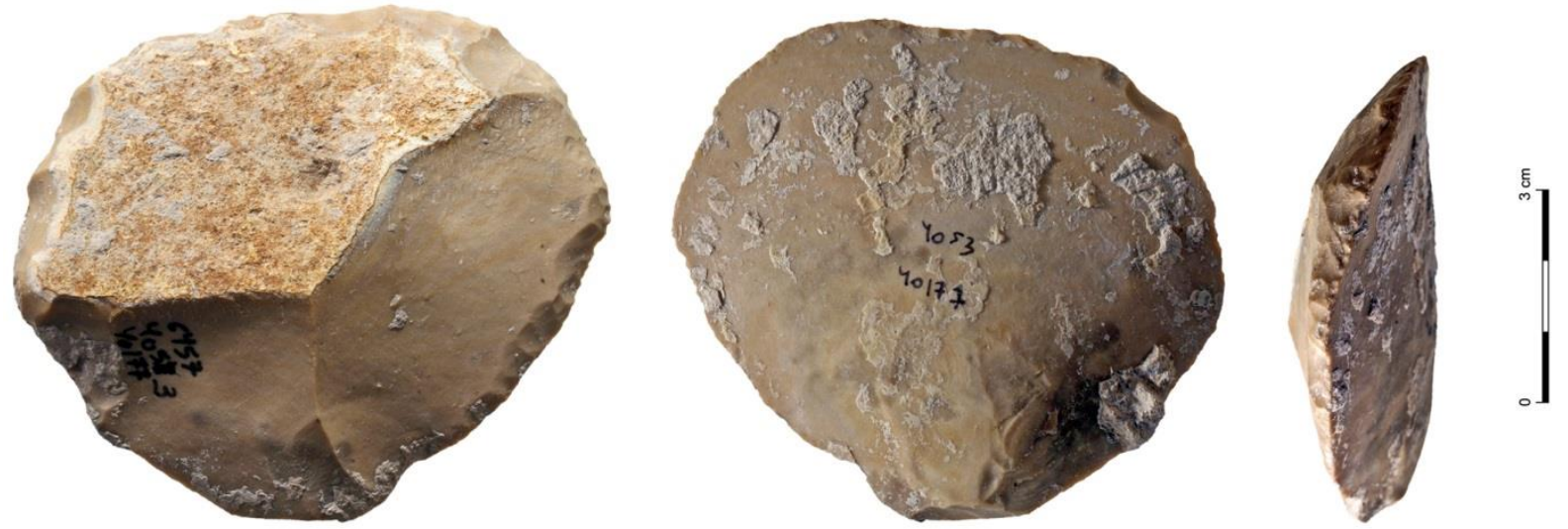

Figure 16. Fan shaped CFS, type B flint, Ein Zippori. Scale bar $=3 \mathrm{~cm}$. 


\subsection{Maintenance and recycling of fan scrapers}

Several aspects of fan scraper maintenance and recycling were examined including the categories listed below.

- 'Burination' - a detachment of one or more burin spalls from the scrapers' working edges. The burination results in an approximately straight angle (nearly $90 \mathrm{deg}$.) between the tool's ventral face and the burin scar. We cannot determine whether fan scrapers were recycled into burins or a burin scar was intentionally added to the scraper.

- 'Resharpening' - in this category we included scrapers that were resharpened after the initial retouch. Those are mainly items that were retouched again removing the bulb of percussion (e.g., Figure 9 below). Apparently, the actual percentage of resharpened tools must be higher than that presented here due to difficulties in determining whether the retouch is initial or post resharpening.

- 'Notch adding' - some of the scrapers demonstrate one to three shaped (by clear retouch) notches that seem to have been added to the scrapers' edge after it was already shaped by retouch. Probably, in some cases, fan scrapers were recycled into notched flakes or blades. However, notches could have been added to a fan scraper's edges, while it still was used as a scraper.

- 'Patinated blank' - a fan scraper that was made on a patinated blank. Patina covers the dorsal or the ventral face of the scraper, but the retouch is fresh, indicating that the scraper was made on an old flake that was produced sometime in the past, before the patina was formed, and then later it was collected and shaped into a scraper. Usually this pattern is described as recycling (Hurst \& Kelly 1961; Belfer-Cohen \& Bar-Yosef 2015).

- 'New flakes detachments' - the removal of small flakes from the ventral or dorsal faces of the scrapers. It can represent an initial stage of maintenance of a fan scraper's working edge; or a mode of recycling the fan scrapers into cores for the production of small flakes (for details see Parush et al. 2016); or a production of Clactonian notches (see also Lemorini et al. 2015; Zupancich et al. 2015).

The modes of 'resharpening' and 'patinated blank' are viewed as trajectories of maintenance and recycling respectively. However, modes of 'burination', 'notches', and 'new flakes detachments' can represent maintenance and recycling, either or both. A breakdown of the above listed categories for fan scrapers and spalls is presented in Table 10. Several fan scrapers appear in more than one category. In total, nearly half (48\%) of CFSs exhibit one or more of the above listed maintenance or recycling aspects, while for FCFSs it is one quarter (27\%). CFSs outnumber FCFSs in each of the categories, but most are in the 'recycling' category of 'patinated blanks'. Fan scraper spalls exhibit several of the listed aspects as well (Table 10). However, nearly all the spalls actually show clear evidence of burination.

Table 10. Fan scrapers life history

\begin{tabular}{lcccccc}
\hline & FCFS \# & FCFS \% & CFS \# & CFS \% & Spalls \# & Spalls \% \\
\hline Burination & 0 & $0 \%$ & 5 & $3 \%$ & -- & -- \\
Resharpening & 4 & $11 \%$ & 25 & $16 \%$ & -- & -- \\
Notch adding & 7 & $19 \%$ & 37 & $24 \%$ & 5 & $14 \%$ \\
Patinated blank & 1 & $3 \%$ & 18 & $12 \%$ & 3 & $9 \%$ \\
New flakes detachments & 3 & $8 \%$ & 17 & $11 \%$ & -- & -- \\
Total of items included in one or & 10 & $27 \%$ & 74 & $48 \%$ & 6 & $17 \%$ \\
more of the listed categories & & & & & & \\
\hline Total number of items & $\mathbf{3 7}$ & & $\mathbf{1 5 4}$ & & $\mathbf{3 5}$ \\
\hline
\end{tabular}




\subsection{Fan scraper spalls}

Two main modes of spall reduction were identified at Ein Zippori $(\mathrm{N}=31)$. In addition, four 'other' spalls were retrieved. One of those is a 'ventral' spall resembling the fan scraper spalls of Megiddo (see Shimelmitz and Adams 2014 for details); the rest are severely damaged and their mode of reduction is not clear:

'Burin spall' - a thin strip of one of the fan scraper edges reduced by a burin blow (Figures 17 and 18).

'Secondary burin spall' - a second burin reduction after a previous one, from the same edge. The result is a thin elongated spall, with fan scraper retouch on a thin portion of the distal end, and the scar of the previous, first burin blow (Figure 19).
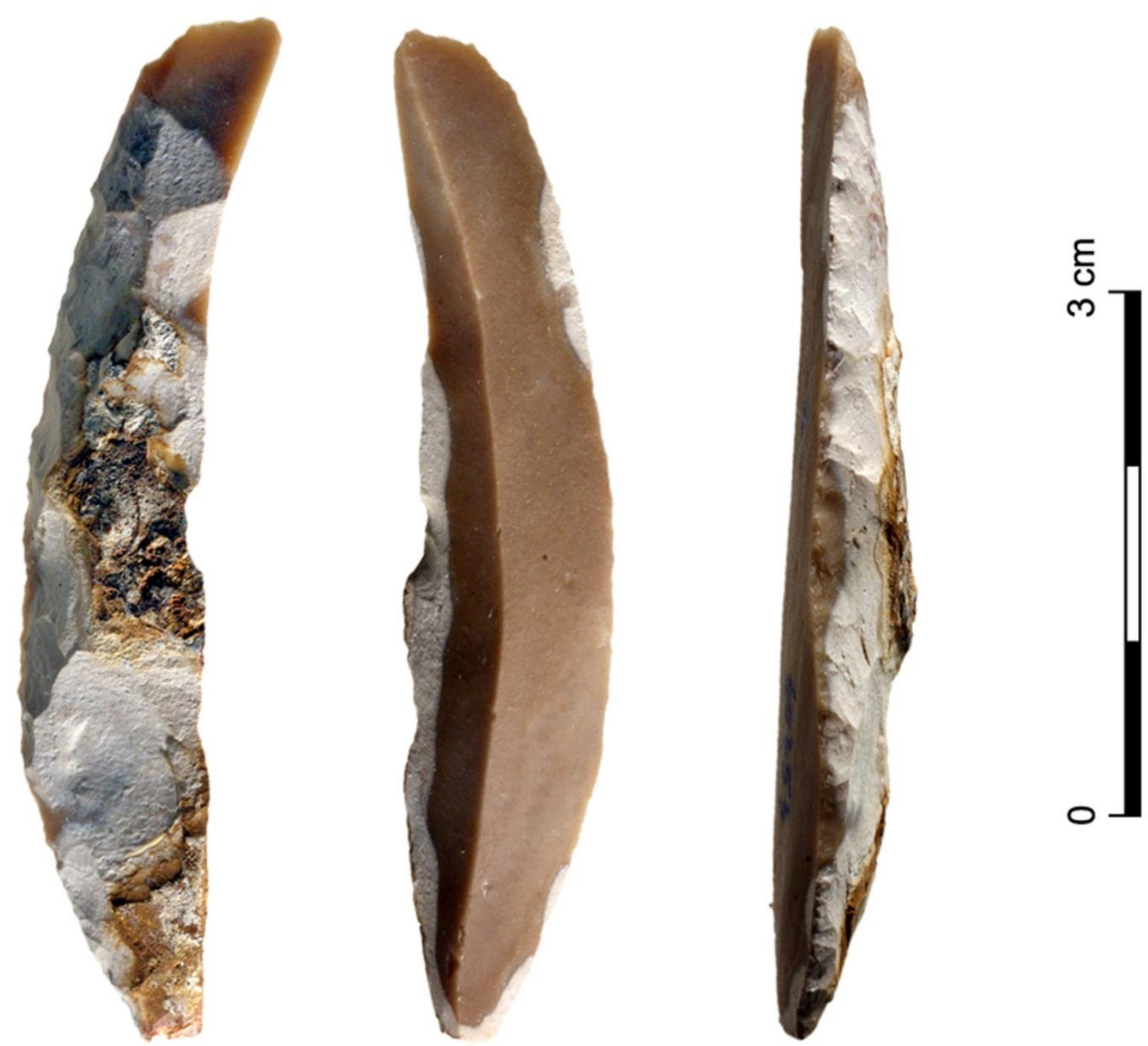

Figure 17. Fan scraper's burin spall, Ein Zippori. From left to right: dorsal face, two ventral faces, dorsal retouch. Type A flint. 

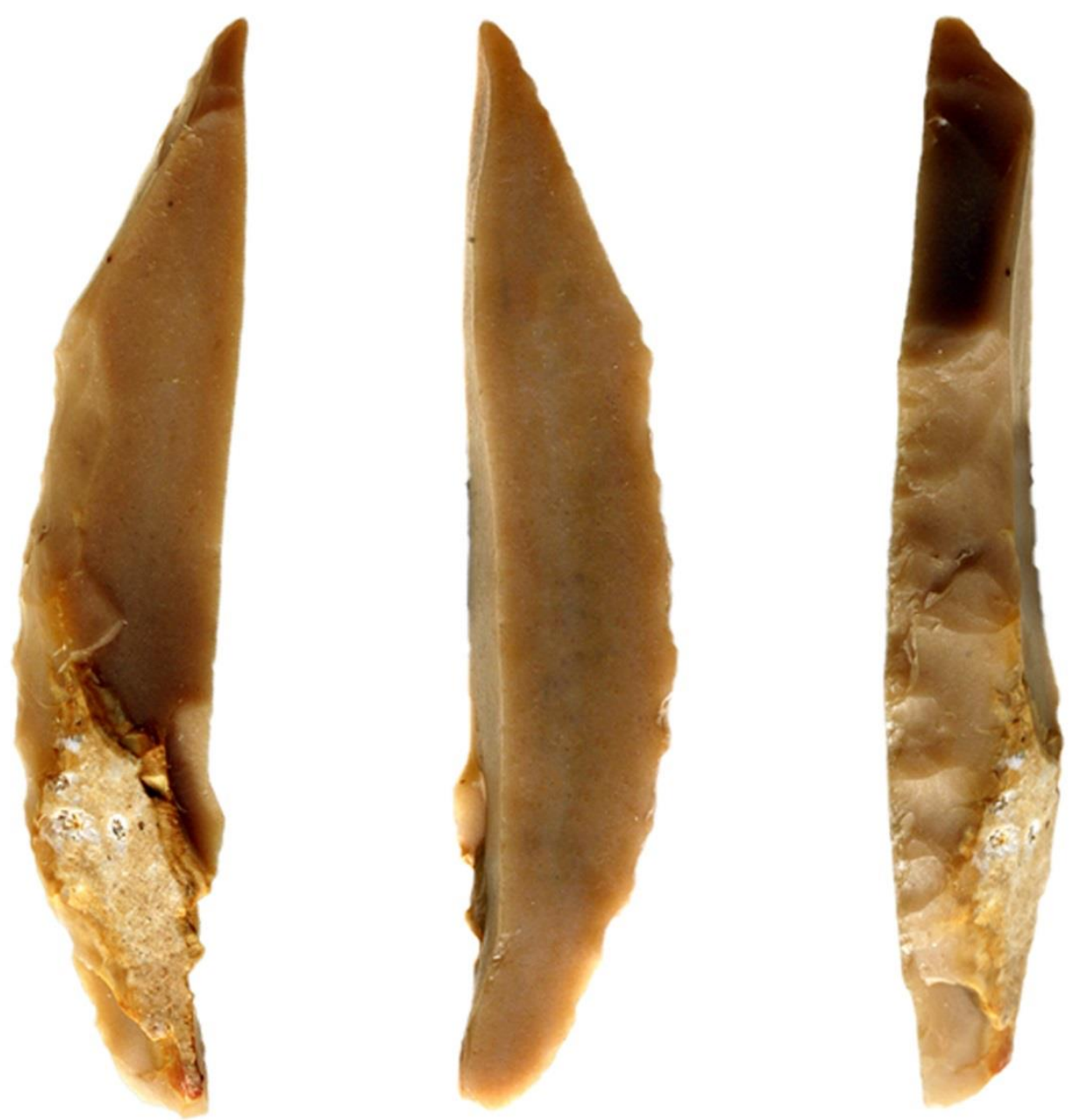

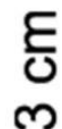

m

Figure 18. Fan scraper's burin spall, Ein Zippori. From left to right: dorsal face, original ventral face, dorsal retouch. Type A flint.
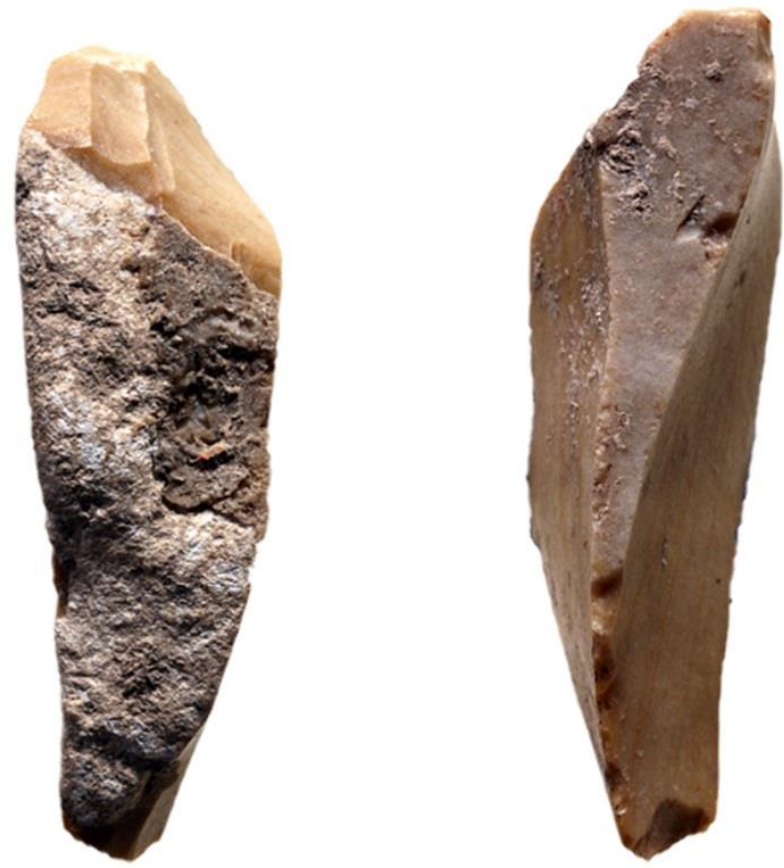

등

m
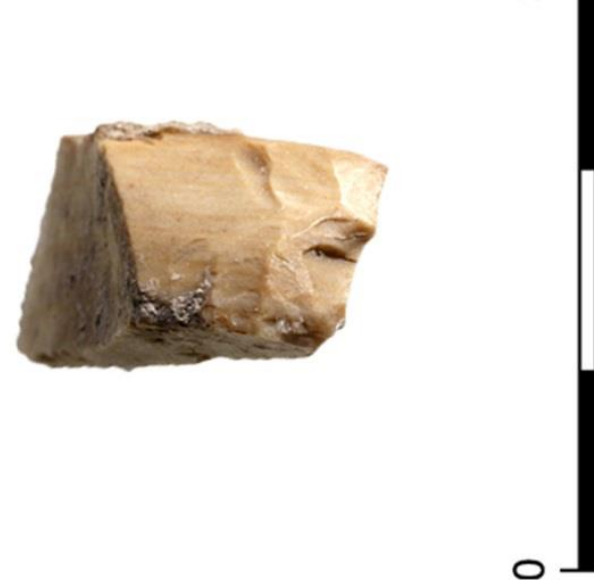

Figure 19. Fan scraper's second burin spall, Ein Zippori. From left to right: dorsal face, two ventral faces and a previous burin scar, a portion of dorsal retouch. Type B flint. 
The breakdown of the above three spall types is presented in Table 11.

Table 11. Fan scraper spalls, Ein Zippori

\begin{tabular}{lll} 
Type of the spall reducing & $\#$ & $\%$ \\
\hline Burination & 23 & $66 \%$ \\
Secondary burination & 8 & $23 \%$ \\
Other & 4 & $11 \%$ \\
\hline Total & $\mathbf{3 5}$ & $\mathbf{1 0 0 \%}$ \\
\hline
\end{tabular}

Burination creates a new edge with a straight angle, not very suitable for semi abrupt retouching. It can be suggested that the burination was intended for 'cleaning' a used or distorted scraper edge in order to create a new edge by retouch. This, we argue, is not the case here since all burin spalls were removed in a nearly 90 degree angle between the burin scar and the ventral face of the scraper, and such an abrupt edge does not facilitate the creation of a new scraper edge by retouch.

Fan scrapers' burin spalls are similar to fan scrapers in edge thickness and edge angle (see Tables 6 and 7, Figure 5), and particularly similar to CFSs in raw material (low proportion of the dark type $\mathrm{D}$, see Table 1). Additionally, burin scars were found only on CFSs so we suggest that spalls were removed mainly from CFS (and probably less from FCFS) likely 'on site', in order to add a burin edge to the scraper.

\section{Results}

The following results were obtained.

- Two distinct groups of fan scrapers were identified according to one technological trait of flat (flat cortex fan scrapers - FCFS) vs. convex (cortical fan scrapers - CFS) dorsal face.

- Technological and typological, as well as raw material analysis conducted on both groups revealed pronounced differences.

- Those techno-typological changes are in accordance with the chronology.

- Based on the techno-typological analysis of Ein Zippori fan scrapers, together with considerations of stratigraphy, pottery analysis, and published materials, we associate most FCFS with the EBA period, and most CFS with WR, in both early and late phases of it.

- We believe that the technological, typological, and chronological changes require an updated definition for fan scrapers and their types.

- Fan scrapers edge angles correlate with function (Yerkes et al. 2016) and this aspect shows no chronological trend - no differences in usewear traces between WR and EBA fan scrapers were observed.

- CFS exhibit higher rates or maintenance and recycling.

- Both FCFS and CFS were apparently more efficient tools compared to other 'side' and 'end', 'not fan' scrapers by means of convenience and duration of use and resharpening, as well as range of tasks (scraping and cutting).

- The Ein Zippori fan scrapers' spalls resemble fan scrapers' working edges in all analyzed parameters. Raw material considerations and the presence of burin scars solely on CFS lead us to associate the spalls mainly with CFS and less so with FCFS.Following our analysis of large samples of fan scrapers from WR and EBA layers of Ein Zippori and a survey of published accounts of late PN, CHG, and EBA fan scrapers, we suggest that fan scrapers can be divided into two major types. The two types also differ from one another in technology and raw material properties and are, in general, chronologically distinct. 
Since there are no CHG layers at Ein Zippori, our proposed typological definition will concentrate on differences between WR and EBA types of fan scrapers. Several distinguishing techno-typological traits of $\mathrm{CHG}$ fan scrapers, based on published accounts, were highlighted in Table 8 .

\section{Fan scraper group}

Blank: Mostly cortical and thin (up to nearly $2.5 \mathrm{~cm}$ ) flake, blade or tabular flint;

Typology: Oval, elongated, fan shaped, round, and irregular;

Technology: dorsal, ventral, or both, abrupt to sharp retouch.

\section{Type 1: Cortical fan scrapers (CFS):}

Blank: Mostly cortical, thin (up to nearly $2.5 \mathrm{~cm}$ ) and plano-convex in cross section flake or blade, with slightly convex dorsal face or thin tabular flint with two cortical faces;

\section{Raw material: local;}

Cores: regular cortical nodules;

Typology: mostly oval (end-struck), but also fan, round, elongated and irregular;

Technology: mostly short (less than a quarter of scraper's length or width) dorsal retouch of varying angles on an average of three edges of the blank; bulb thinning - rare;

Period: most common in late PN.

\section{Type 2: Flat cortex fan scrapers (FCFS):}

Blank: Cortical, thin (up to nearly $1.5 \mathrm{~cm}$ ) and flat flake or blade;

Raw material: local or imported;

Cores: nodules (tabular flint) with flat cortex;

Typology: mostly elongated (end-struck) but also oval and fan;

Technology: mostly short dorsal retouch of varying angles on an average of three edges of scraper's blank; no bulb thinning; incised cortex - common;

Period: most common in EBA.

\section{Discussion and conclusions}

WR (Late PN) fan scrapers are represented mainly by Cortical Fan Scrapers (CFS). CFS sharply differ from 'end' and 'side' scrapers, as they are retouched on three edges on average, resemble later fan scrapers by blank flatness and cortex retention which enables a comfortable grasp, and exhibit edge properties similar to FCFS. Contrary to the 'end' and 'side' scrapers characteristic of Ein Zippori, fan scrapers are designed so that they may be repetitively retouched forming various edge angles, enabling the use of the tool as a scraper and as a knife at the same time. Moreover, fan scrapers could be resharpened to a significant extent since they were made on large, homogenous blanks, and thus provide a potential for a longer use life than smaller 'side' and 'end' scrapers. Thus, we suggest that CFS represent an initial form, or a precursor, of the later $\mathrm{CHG}$ and EBA fan scrapers.

During the EBA, we witness more specialized manufacturing of fan scrapers with clear raw material preferences of dark flint with a flat cortical face; technological skills and standards in production of large blanks (mainly blades), mostly with even thickness along the entire blank's length; and low rates of recycling and maintenance. Apparently, FCFS represent a specialized technology using probably non-local lithic raw materials.

Our impression is that specialized flint tool production trajectories in EBA layers of Ein Zippori (e.g., FCFS and Canaanean blades) are not widespread (e.g., FCFS account for 8$12 \%$ of all of the scrapers in analyzed EBA layers). Thus, it is not surprising that CFSs are 
present to a minor extent, even in Ein Zippori EBA contexts showing homogeneous pottery assemblages. This may be the result of intrusion or 'curation' of older lithic items from underlying WR layers, but it may also show that there was a continuation of the old traditional Neolithic technology side by side with specialization in fan scraper production. An element of continuity from PN to CHG and EBA has been noticed by others too (e.g., Smith et al. 1997; Noy 1998: 277)

FCFS were retrieved in small numbers also from Ein Zippori context showing homogeneous WR pottery assemblages (including one WR wall and one floor). If these FCFS-type scrapers are present in WR layers at other sites (based on the published fan scrapers profiles, see Kaplan 1969, fig. 12.4; Barkai \& Gopher 2012: 838, 839, figs. 19.43.4, 19.44.2), mixing alone may not account for them. We suggest that two different production trajectories (specialized and local) were present at Ein Zippori during WR and EBA, however in varying frequencies.

While WR and EBA fan scrapers represent two technologically distinct production trajectories, the characteristics of edge angles and thickness are similar in CFS and FCFS. This argument was strengthened by usewear analysis of both CFS and FCFS, as well as spalls from Ein Zippori (Yerkes et al. 2016) indicating no difference in function between them. Functional analysis revealed that fan scrapers were efficient tools in exploiting animals' carcasses and hide processing (Yerkes et al. 2016). Mostly all fan scrapers edges analyzed were applied in butchering, skinning, defleshing as well as for hide and bone working tasks. An interesting correlation was found between the different edge properties and the tasks performed. Abrupt to semi abrupt edge angles were used mostly for scraping, while sharper edges were used also for cutting. We can conclude that the working edges' thickness and angles were functionally relevant and similar in both scraper types. In contrast, technological traits (e.g., flat dorsal face, dark raw material, even thickness of the blank, fan vs. elongated shape, incisions, etc.) may be related to the degree of production standardization, but at the same time may also reflect cultural choices and preferences.

While relatively scarce in the Mediterranean zone of the southern Levant, fan scrapers were abundant in pastoral nomad sites of north and south Jordan, the Negev and Sinai (Rosen 1983; McCartney 1992; McCartney \& Betts 1998; Beit Arieh et al. 2003; Fujii 2006; Abe 2008; Akkermans et al. 2014; Rollefson et al. 2014) and have been associated with the management of large herds beginning probably as early as the PN (McCartney \& Betts 1998; Akkermans et al. 2014; Rollefson et al. 2014; Athanassas et al. 2015; Rowan et al. 2015). The term 'pastoralist' holds many levels of meaning, and while the essence of this term relates to the 'foundation of the management of domesticated animals' (Rollefson et al. 2014 and references therein), the origins of such pastoral societies and the question of their socioeconomic independence is of major importance. Following a model suggesting that their origins are in PN societies in the Mediterranean zone (Gopher 2012: 1570-1575), it was suggested that alongside with an economy based on animal herding, those nomad populations were also involved in additional subsistence activities (see Gopher 2012: 1570-1575) e.g., the production and exchange of beads, procurement of raw material and production of tabular scrapers and later, possibly even activities related to the metal industry (Rosen 1983; 1997: 75; Quintero et al. 2002; Wright \& Garrard 2003; Müller-Neuhof 2006; 2013; Fujii 2011; Klimscha 2011; Abu-Azizeh 2013; Milevski 2013).

With this model and the fan scraper analysis presented here we should associate the specialized Flat Cortex Fan Scrapers (FCFS) production and exchange with nomadic herding populations. We found that fan scrapers had technological and functional advantages over other types of scrapers ('end' and 'side') and this turned them into popular tools during the $\mathrm{CHG}$ and the EBA. It might be important to notice that while Cortical Fan Scrapers (CFS) are present in the Mediterranean zone and arid margins such as the Azraq Basin, eastern Jordan, 
already in the late PN, the standardized FCFS industry became a sort of specialized activity and part of an exchange system among the pastoral nomadic population only later in the CHG and the EBA (Rosen 1983; 1997: 75; Quintero et al. 2002; Fujii 2011).

Fan scrapers were likely designed for efficient skinning, butchering, and hide processing tasks. They became more common and standardized in late prehistoric periods, and apparently also had cultural, social and perceptual meanings, aspects which will be discussed in a separate paper.

\section{Acknowledgements}

The excavations at Ein Zippori were conducted on behalf of the Israel Antiquity Authority and were funded by the National Company of Roads. We would like to thank the staff of the excavation, to Pasha Shrago for the photos of flint items, and to Heeli Schechter and Natasha Solodenko for the figures editing. We would also like to express a deep appreciation to two anonymous reviewers for improving this paper by constructive suggestions, and to Prof. Ran Barkai who made important comments on the manuscript.

\section{References}

Abe, M. 2008, The Development of urbanism and pastoral nomads in the Southern LevantChalcolithic and Early Bronze Age stone tool production industries and flint mines in the Jafr Basin, Southern Jordan. Doctoral thesis, University of Liverpool, Liverpool, $555 \mathrm{p}$.

Abu-Azizeh, W. 2013, The south-eastern Jordan's Chalcolithic-Early Bronze Age pastoral nomadic complex: patterns of mobility and interaction, Paléorient, 39(1): 149-176. URL: http://www.jstor.org/stable/43576769

Agam, A., Walzer, N., Schechter, H., Zutovski, K., Milevski, I., Getzov, N., Gopher, A., \& Barkai, R. 2016. Organized waste disposal in the Pottery Neolithic: A bifacial workshop refuse pit at Ein Zippori, Israel, Journal of Field Archaeology, 41(6): 1-18. doi:10.1080/00934690.2016.1240598

Akkermans, P. M. M. G., Huigens, H. O., \& Brüning, M. L. 2014, A landscape of preservation : late prehistoric settlement and sequence in the Jebel Qurma region, northeastern Jordan, Levant, 46(2): 186-205. doi:10.1179/0075891414Z.00000000041

Athanassas, C. D., Rollefson, G. O., Kadereit, A., Kennedy, D., Theodorakopoulou, K., Rowan, Y. M., \& Wasse, A. 2015, Optically stimulated luminescence (OSL) dating and spatial analysis of geometric lines in the Northern Arabian Desert, Journal of Archaeological Science, 64: 1-11. doi:10.1016/j.jas.2015.09.005

Avner, U. 2002, Studies in the material and spiritual culture of the Negev and Sinai populations, during the 6th-3rd millennia BC. Doctoral thesis, Institute of Archaeology, Hebrew University, Jerusalem, 388 p.

Avrutis, V. W., \& Golding-Meir, N. 2012, Late Chalcolithic and Early Bronze Age I Remains at Nesher-Ramla Quarry, (van den Brink, E.C., Ed.), Zinman Institute of Archaeology, $286 \mathrm{p}$.

Bankirer, R. Y., \& Marder, O. 2003, The flints from Tel Gat-Hefer, Antiquity, 44: 139-142. URL: http://www.jstor.org/stable/23461390 
Bar-Yosef, O., Belfer, A., Goren, A., \& Smith, P. 1977, The nawamis near' Ein Huderah (Eastern Sinai), Israel Exploration Journal, 27(2-3): 65-88.

Barkai, R., \& Gopher, A. 2012, Flint assemblages from Nahal Zehora II: Techno-typological changes during the PN. In: Village Communities of the Pottery Neolithic Period in the Menashe Hills, Israel: Archaeological Investigations at the sites of Nahal Zehora, (Gopher, A., Ed.), Emert and Claire Yass Emert and Claire Yass Publications in Archaeology, Institute of Archaeology, Tel Aviv University, Tel Aviv: p. 757-869.

Barket, T.M., \& Bell, C.A. 2011, Tabular Scrapers: Function Revisited, Near Eastern Archaeology, 74(1): 56-59. doi:10.5615/neareastarch.74.1.0056

Barzilai, O. \& Milevski, I. 2015, Neolithic flint workshops at Givat Rabi East in the Lower Galilee, Atiqot, 82: 1-21.

Barzilai, O., Getzov, N., Gobenko, N., Marom, N., Milevski, I., Vered, A. \& Zheng, J. 2013, Proto-Historic Ein Zippori: The 2007 Excavation Season, Mitekufat Haeven: Journal of the Israel Prehistoric Society, 43: 22-72.

Beit-Arieh, I. 2003, Archaeology of Sinai.The Ophir Expedition Vol. 21, Emert and Claire Yass Publications in Archaeology, Institute of Archaeology, Tel Aviv University, Tel Aviv, $454 \mathrm{p}$.

Belfer-Cohen, A., \& Bar-Yosef, O. 2015, Paleolithic recycling: The example of Aurignacian artifacts from Kebara and Hayonim caves, Quaternary International, 361: 256-259. doi:10.1016/j.quaint.2014.06.008

Blockman, N., \& Groman-Yeroslavski, I. 2006, The Early Bronze Age flint assemblage. In: Megiddo IV: The 1998-2000 Seasons, (Finkelstein, I., Ussishkin, D., \& Halpern, B., Eds.), Monograph Series of the Institute of Archaeology of Tel Aviv University, Emery and Claire Yass Publications, 24, Tel Aviv: p. 315-342.

van den Brink, E., Horwitz, L. K., Khalaily, H., Liphschitz, N., Mienis, K., \& Nagar, Y. 2004, A Chalcolithic Dwelling and Burial Cave at Horvat Castra, Israel Exploration Journal, 54(2): 129-153. URL: http://www.jstor.org/stable/27927073

Bron, H. 2010, Had-Nes, Hadashot Arkheologiyot, Excavations and Surveys in Israel, 122.

Crowfoot-Payne, J. 1983, The flint industries of Jericho. In: Excavations at Jericho Vol. V (Kenyon, K.A., \& Holland, T.A., Eds.), London: British School of Archaeology in Jerusalem: p. 622-759.

Dag, D., \& Garfinkel, Y. 2007, The flint industry of Tel Tsaf, a middle Chalcolithic site in the Jordan valley, Israel, Mitekufat Haeven: Journal of the Israel Prehistoric Society, 37: 381-417. URL: http://www.jstor.org/stable/23383640

Ekshtain, R., O. Barzilai, M. Inbar, I. Milevski, \& Ullman, M. 2012, Givat Rabi East, a new Middle Paleolithic knapping site in the Lower Galilee (Israel), Paléorient, 37(2): 107122. URL: http://www.jstor.org/stable/43265271

Epstein, C. 1984, A Pottery Neolithic Site near Tel Qatif, Israel Exploration Journal, 34(4): 209-219. URL:http://www.jstor.org/stable/27925948

Fujii, S. 1998, Qa` Abu Tulayha West: An Interim Report of the 1997 Season, Annual of the Department of Antiquities of Jordan, 42: 123-140.

Fujii, S. 1999, Qa`Abu Tulayha West: An Interim Report of the 1998 Season, Annual of the Department of Antiquities of Jordan, 43: 69-89. 
Fujii, S. 2000, Qa`Abu Tulayha West: An Interim Report of the 1999 Season, Annual of the Department of Antiquities of Jordan, 44: 149-171.

Fujii, S. 2001, Qa`Abu Tulayha West, 2000: An interim of the fourth season, Annual of the Department of Antiquities of Jordan, 45: 19-37.

Fujii, S. 2002, Qa Abu Tulayha West, 2001: An interim of the fifth season, Annual of the Department of Antiquities of Jordan, 46: 15-39.

Fujii, S. 2006, Wadi Abu Tulayha: A preliminary report of the 2005 spring and summer excavation seasons of the Jafr Basin Prehistoric Project, Phase2, Annual of the Department of Antiquities of Jordan, 50: 9-31.

Fujii, S. 2011, "Lost Property" at Wadi Qusayr 173: Evidence for the Transportation of Tabular Scrapers in the Jafr Basin, Southern Jordan, Levant, 43(1): 1-14. doi:10.1179/007589111X12966443320738

Garfinkel, Y. 2007, The Pre-Pottery Neolithic B Naviform Industry of Yiftahel. In: Technical Systems and Near Eastern PPN Communities; Proceedings of the 5th International Workshop, Fréjus, 29th February-5th March, 2004, Antibes (Astruc, L., Binder, D., \& Briois, F., Eds.), Antibes: p. 203-213.

Getzov, N. 2013, Flint Assemblage, In: Peqi'in. A Late Chalcolithic Burial Site, Upper Galilee, Israel, (Shalem, D., Gal, Z., \& Smithline, H., Eds.), Jerusalem: p. 293-318.

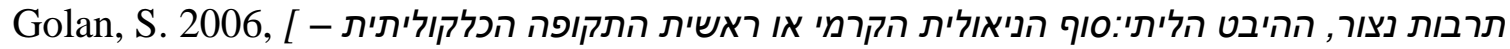
[ מקרה מבחן מהאתר נצור Nazur culture, lithic perspective. Master of Arts thesis thesis at Tel Aviv University, Tel Aviv, 93 p. (in Hebrew) ("The Nazur Culture, a lithic perspective: A case study from the site Nazur 4 - The end of the Pottery Neolithic or the beginning of the Chalcolithic period")

Gopher, A. 1989, The flint assemblages of Munhata (Israel), final report. Paris: (Les Cahiers du Centre de Recherche Francais de Jerusalem) Association Paléorient, 162 p.

Gopher, A. 2012, The pottery Neolithic in the Southern Levant: A second Neolithic Revolution. In: Village Communities of the Pottery Neolithic Period in the Menashe Hills, Israel: Archaeological Investigations at the sites of Nahal Zehora, (Gopher, A., Ed.), Emert and Claire Yass Publications in Archaeology, Institute of Archaeology, Tel Aviv University, Tel Aviv: p. 1525-1611.

Greenhut, Z. 1989, [נלי הצור - מצפה שלם] Mispeh Shalem - Flint Tools. In: Excavations in the Judean Desert (Bar-Adon, P., Ed.), 'Atīqōt [Hebrew Series] Vol. 9, Atīqōt, Jerusalem: p. 60-78. (in Hebrew) ("Mispeh Shalem - Flint Tools")

Henry, D.O. 1995, Prehistoric Cultural Ecology and Evolution: Insights from Southern Jordan. Plenum Press, New York, 466 p.

Hurst, V. J., \& Kelly, A. R. 1961, Patination of Cultural Flints: Flint artifacts can be dated by cortical changes in mineralogy and texture, Science, 134 (3474): 251-256. doi:10.1126/science.134.3474.251

Kaplan, J. 1969, Ein el Jarba: Chalcolithic remains in the plain of Eshdraelon, Bulletin of the American Schools of Oriental Research, 194: 2-39. doi:10.2307/1356425 


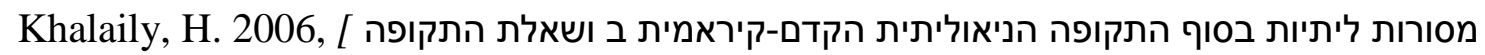
[הניאוליתית הקדם קיראמית ג בדרום הלבנט Lithic Traditions during the Late Pre-Pottery Neolithic B and the Question of the Pre-Pottery Neolithic C in the Southern Levant. Doctoral thesis, Ben-Gurion University of the Negev, Beer Sheva, 411 p. (in Hebrew) ("Lithic Traditions during the Late Pre-Pottery Neolithic B and the Question of the PrePottery Neolithic C in the Southern Levant")

Khalaily, H. 2011, Nahal Yarmut: A Late Pottery Neolithic Site of the Wadi Rabah culture, south of nahal Soreq, Atiqot, 67: 1-29. URL: http://www.jstor.org/stable/23467129

Kalaily, H. \& Nagorsky, A. 2013, Tel Hanan: A Site of the Wadi Rabah Culture East of Haifa, Atiqot, 73: 1-17. URL: http://www.jstor.org/stable/23466590

Khalaily, H., Kuperman, T., Marom, N., Milevski, I., \& Yegorov, D. 2015, Beisamun: An Early Pottery Neolithic Site in the Hula Basin, 'Atiqot, 82: 1-61.

Klimscha, F. 2011, Long-range contacts in the late Chalcolithic of the southern Levant. Excavations at Tall Hujayrat al-Ghuzlan and Tall al-Magass near Aqaba, Jordan, In: Egypt and the Near East - the crossroads, (Mynarova, J. Ed.), Charles University Prague, Czech Institute of Egyptology, Faculty of Arts, Prague: p. 177-209.

Kochavi, M. 1969, Excavations at Tel Esdar, 'Atiqot [HS], 5: 2-5. URL: http://www.jstor.org/stable/23456276

Lemorini, C., Bourguignon, L., Zupancich, A., Gopher, A., \& Barkai, R. 2015, A scraper's life history: Morpho-techno-functional and use-wear analysis of Quina and demi-Quina scrapers from Qesem Cave, Israel, Quaternary International, 398: 86-93. doi:10.1016/j.quaint.2015.05.013

Levy, T. E., \& Alon, D. 1985, The Chalcolithic Mortuary Site near Mezad Aluf, Northern Negev Desert: Third Preliminary Report, 1982 Season, Bulletin of the American Schools of Oriental Research. Supplementary Studies, 23: 121-135.

URL: http://www.jstor.org/stable/20066654

Marder, O., Braun, E., \& Milevski, I. 1995, The Flint Assemblage of Lower Horvat' Illin : Some Technical and Economic Considerations, 'Atiqot, 27: 63-93.

URL: http://www.jstor.org/stable/23458198

McCartney, C. J. 1992, Preliminary Report of the 1989 Excavations at Site 27 of the Burqu/Ruweishid Project, Levant, 24(1), 33-54. doi:10.1179/007589192790218264

McCartney, C., \& Betts, A. 1998, Dhuweila: Chipped Stone. The Harra and the Hamad. In: Excavations and Explorations in Eastern Jordan, (Betts. A., Ed.), Vol 1. Sheffield Academic Press Ltd: p. 59-119.

McConaughy, M.A. 1979, Formal and Functional Analyses of the Chipped Stone Tools from Bâb edh-Dhrâ, Jordan. Doctoral thesis, Department of Anthropology, University of Pittsburgh. 431 p.

McConaughy, M.A. 1980, Chipped Stone Tools. In: Preliminary Report of the 1979 Expedition to the Dead Sea Plain, Jordan. Bulletin of the American Schools of Oriental Research 240:53-59. doi:10.2307/1356536

Milevski, I. 2013, The Exchange of Flint Tools in the Southern Levant during the Early Bronze Age. Lithic Technology, 38(3): 202-219. doi:10.1179/0197726113Z.00000000021 
Milevski, I., Liran, R., \& Getzov, N. 2014, The Early Bronze Age town of Ein Zippori in the Galilee (Israel), Antiquity, 88(339): 2-5.

URL: http://antiquity.ac.uk/projgall/milevski339/

Milevski, I., Barzilai, O., Getzov, N., \& Vered, A. 2015a. An Animal Relief from'Ein Zippori, Lower Galilee. Ugarit-Forschungen, (46): 289-298.

Milevski, I., Getzov, N., Galili, E., Horwitz, L.K., \& Yaroshevich, A. 2015b, Die Palette von Ein Zippori und altere weibliche Kompositfiguren aus dem sechsten und fünften Jahrtausend v.u.Z. in der südliche Levante und in Mesopotamien. Das Altertum, 60: 241-262.

Milevski, I., Getzov, N., Galili, E., Yaroshevich, A., \& Horwitz, L.K. 2016. Some Iconographic Motifs from the 6th-5th Millennia BC in the Levant and Mesopotamia: Clues for Cultural Connections and the Existence of an Interaction Sphere. Paléorient 42(2): 141-155.

Müller-Neuhof, B. 2006, Tabular scraper quarry sites in the Wadiar-Ruwayshid region (N/E Jordan), Annual of the Department of Antiquities of Jordan, 50: 373-383.

Müller-Neuhof, B. 2013, Southwest Asian Late Chalcolithic/Early Bronze Age Demand for "Big-Tools": Specialized Flint Exploitation Beyond the Fringes of Settled Regions, Lithic Technology, 38(3): 220-236. doi:10.1179/0197726113Z.00000000022

Namdar, D., Amrani, A., Getzov, N., \& Milevski, I. 2015. Olive oil storage during the fifth and sixth millennia BC at Ein Zippori, Northern Israel, Israel Journal of Plant Sciences, 62(1-2): 65-74. doi:10.1080/07929978.2014.960733

Noy, T. 1998, The flint artifacts. In: The Chalcolithic culture of the Golan, (Epstein, C., Ed.), IAA Report: Israel Antiquity Authority, Jerusalem: p. 269-332.

Oshri, A., Khalaily, H., Milevski, I., \& Marder, O. 1999, Yiftah'el (Northeast; Triangulation Point Q-1), Hadashot Archeologiot-Excavations and Surveys in Israel, 110: 89.

Parush, Y., Efrati, B., Milevski, I., Getzov, N., Gopher, A., \& Barkai, .R. (Oct. 2016). Recycling in the Neolithic, Evidence of flint recycling at Ein Zippori, Israel. Manuscript in preparation, unpublished. $29 \mathrm{p}$.

Quintero, L., Wilke, P., \& Rollefson, G. 2002, From Flint Mine to Fan Scraper: The Late Prehistoric Jafr Industrial Complex, Bulletin of the American Schools of Oriental Research, 327: 17-48. doi:10.2307/1357856

Rizkana, I., \& Seeher, J. 1988, Maadi 2.The Lithic Industries of the Predynastic Settlement (AV 65), Mainz, $115 \mathrm{p}$.

Rollefson, G., Rowan, Y., \& Wasse, A. 2014, The Late Neolithic colonization of the Eastern Badia of Jordan, Levant, 46(2): 285-301. doi:10.1179/0075891414Z.00000000046

Rosen, S.A. 1983, The Tabular Scraper Trade: A Model for Material Cultural Dispersion, Bulletin of the American Schools of Oriental Research, 249: 79-86. doi: $10.2307 / 1356563$

Rosen, S.A. 1993. The Lithic Assemblages from Nahal Mitnan. 'Atiqot, 22: 62-69. URL: http://www.jstor.org/stable/23457075

Rosen, S.A. 1997, Lithics After the Stone Age. Walnut Creek, Altamira, 184 p. 
Rosen, S.A., Hermon, S., Vardi, J., \& Abadi, Y. 2006, The chipped stone assemblage from Be'er Resisim: A preliminary study, In: Confronting the Past: Festschrift in Honor of William G. Dever, (Gittin, S., \& Wright, T., Eds.), Bulletin of the American Schools of Oriental Research, Winona lake Indiana: p. 133-144.

Rosen, S. 2013, Arrowheads, Axes, Ad Hoc, and Sickles: An Introduction to Aspects of Lithic Variability across the Near East in the Bronze and Iron Ages, Lithic Technology, 38(3): 141-149. doi:10.1179/0197726113Z.00000000023

Rowan, Y.M., \& Levy, T. 1991, Use wear analysis of a Chalcolithic scraper assemblage from Shiqmim, Journal of the Israel Prehistoric Society, 24: 112-134.

URL: http://www.jstor.org/stable/23373361

Rowan, Y. M. 2006, The chipped stone assemblage at Gilat, In: Archaeology, anthropology and cult: The sanctuary at Gilat, (Levy, T.E., Ed.), Equinox Pu, London: p. 507-574.

Rowan, Y. M., Rollefson, G. O., Wasse, A., Abu-azizeh, W., Hill, A. C., \& Kersel, M. M. 2015, The land of conjecture: New late prehistoric discoveries at Maitland's Mesa and Wisad, Journal of Field Archaeology, 40(2): 176-189. doi:10.1179/0093469015Z.000000000117

Schechter, H. C., Gopher, A., Getzov, N., Rice, E., Yaroshevich, A., \& Milevski, I. 2016a, The Obsidian Assemblages from the Wadi Rabah Occupations at Ein Zippori, Israel, Paléorient 42(1): 29-52.

Schechter, H. C., Zutovski, K., Agam, A. Getzov, N., Milevski, I. \& Gopher, A. (Aug. 2016b). Refitting Bifacial Production Waste - the Case of the Wadi Rabah Refuse Pit from Ein Zippori, Israel. Manuscript in preparation, unpublished. $44 \mathrm{p}$.

Shimelmitz, R., \& Adams, M. J. 2014, Flint knapping and the Early Bronze Age I temple of Megiddo, Israel: Some aspects of the organization of late prehistoric cult, Journal of Mediterranean Archaeology, 27(1): 51-78. doi:10.1558/jmea.v27i1.51

Shimelmitz, R., \& Rosen, S. A. 2014, The flint assemblage, In: Bet Yerah:The Early Bronze Age mound, Volume II. Urban structure and Material culture, 1933-1986 excavations, (Greenberg, R.,Ed.), IAA: p. 151-188.

Smith, A. M., Stevens, M., \& Niemi, T. M., 1997, The Southeast Araba Archaeological Survey: A preliminary report of the 1994 season, Bulletin of the American Schools of Oriental Research, 305: 45-71. doi:10.2307/1357745

Stekelis, M. 1972, TheYarmukian Culture of the Neolithic Period. Magnes Press, Jerusalem, $45 \mathrm{p}$.

Stępień, U. 2012, Tabular scrapers from the Eastern Kom at Tell el-Farkha, Studies in Ancient Art and Civilization, 16: 75-84.

Unger-Hamilton, R. 1991, The Microwear Analysis of Scrapers and "Sickle Blades", In: Excavations at Jawa 1972-1986: Stratigraphy, Pottery, and Other Finds. Excavations and Explorations in the Hashemite Kingdom of Jordan Vol. 1, (Betts, A.V.G., Ed.), Edinburgh University Press, Edinburgh: p. 149-153, 351.

Wada, H. 2001, The chipped stone tools, In: Jebel Abu Thawwab (Er-Rumman), Central Jordan. The Late Neolithic and Early Bronze Age I Occupations, (Kafafi, Z., Ed.), Berlin: Ex Oriente: p.117-154. 
Wilson, L., \& Agam, A. (Oct. 2016). Patterns of flint procurement and exploitation in Neolithic and Early Bronze Age Assemblages from Ein Zippori, Israel. Manuscript in preparation, unpublished. $62 \mathrm{p}$.

Wright, K., \& Garrard, A. 2003, Social identities and the expansion of stone bead-making in Neolithic Western Asia: new evidence from Jordan, Antiquity, 77(296): 267-284. doi:10.1017/S0003598X00092267

Yannai, E., \& Ariel, D. T. 2006, 'En Esur ('EinAsawir) I: excavations at a protohistoric site in the coastal plain of Israel Vol. 1. Israel Antiquities Authority, $302 \mathrm{p}$.

Yeivin, E., \& Olami, Y. 1979, Nizzanim-A Neolithic Site in Nahal Evtah: Excavations of 1968-1970, Tel Aviv, 6(3-4): 99-135. doi:10.1179/033443579788441154

Yerkes, R. W., Barkai, R., Gopher, A., \& Zutovski, K. 2016, The use of fan scrapers: Microwear evidence from late Pottery Neolithic and Early Bronze Age Ein Zippori, Israel. Journal of Lithic Studies, 3(1): 21 p. doi:10.2218/jls.v3i1.1447

Zupancich, A., Lemorini, C., Gopher, A., \& Barkai, R. 2015, On Quina and demi-Quina scraper handling: Preliminary results from the late Lower Paleolithic site of Qesem Cave, Israel. Quaternary International, 398: 94-102. doi:10.1016/j.quaint.2015.10.101 